\title{
Change in heathland fire sizes inside vs. outside the Bale Mountains National Park, Ethiopia, over 50 years of fire-exclusion policy: lessons for REDD+
}

\author{
$\underline{\text { Maria U. Johansson }}^{1}, \underline{\text { Senait D. Senav }}^{2}$, Emma Creathorn $^{3}, \underline{\text { Habtemariam Kassa }}^{4}$ and $^{\text {Kristoffer Hylander }}{ }^{1}$
}

\begin{abstract}
In flammable shrublands fire size often depends on local management. Policy and land use change can drastically alter fire regimes, affecting livelihoods, biodiversity, and carbon storage. In Ethiopia, burning of vegetation is banned, but the burn ban is more strongly enforced inside the Bale Mountains National Park. We investigated if and how policy and land use change have affected fire regimes inside/outside the park. The park was established in 1969, and both studied areas have been part of a new REDD+ project since 2013. Our hypothesis is that burnt heathland stands are nonflammable and act as fuel breaks, and hence that reduced ignition rates leads to larger fires. To quantify change we analyzed remote-sensed imagery from 10 fire-seasons between 1968 and 2017 , quantifying sizes of resprouting Erica stands and recording their postfire age. To elucidate underlying mechanisms of change we interviewed 41 local smallholders. There was a five order of magnitude variation in patch size $(<0.01->1000$ ha). A significant interaction was found between year and site (inside/outside park) in explaining patch size, indicating that the park establishment has affected fire size. Inside the park there was a tendency of patch size increase and outside a clear decrease. Especially the largest fires ( $>$ $100 \mathrm{ha}$ ) increased in numbers inside the park but not outside. Respondents confirmed that large fires have increased in frequency and attributed this mainly to lack of fuel breaks and the fact that fires today are ignited in a more uncontrolled manner later in the dry season. Outside the park respondents explained that fires have become smaller because of increased ignition and intensified grazing. Both situations degrade pasture and threaten Erica shrub survival. For flammable ecosystems, REDD+ fire-exclusion policies need updating, and in this case complemented with a community-based fire management program making use of the vivid local traditional fire knowledge.
\end{abstract}

Key Words: Afromontane; cultural landscapes; Erica arborea; Erica trimera; fuel breaks; indigenous fire management; land use history; patch burning; remote-sensed Imagery; traditional ecological knowledge

\section{INTRODUCTION}

\section{Natural and anthropogenic fire regimes}

Around the world flammable shrublands have traditionally been managed by fire to reduce canopy cover, increase forage production, and to get rid of predators and pests (Keeley et al. 2012). This ancient management is well-known for grassy biomes (Bowman et al. 2011, Archibald et al. 2012), but was common also in heathlands (Hobbs and Gimingham 1987, Wesche et al. 2000) and flammable shrublands (Neumann et al. 2011, Keeley et al. 2012, Pausas and Fernández-Muñoz 2012). Without an understanding of the local fire ecology and management history, there is a risk that new land-management policies, such as climate mitigation projects like REDD+ (Reducing Emissions from Deforestation and forest Degradation, the role of conservation, sustainable management of forests and enhancement of forest carbon stocks in developing countries) may cause unintended negative consequences. Examples could be loss of biodiversity and reduced food security, or a shift in the fire regime, resulting in larger more destructive fires.

Natural and anthropogenic fire regimes can be difficult to separate in paleorecords, and prehistoric management is often unknown (Archibald 2016). Flammable shrublands can also be naturally ignited by lightning, and, e.g., some dry shrublands in Australia have likely been little influenced by prehistoric human ignition (Bradstock et al. 2012, Keith et al. 2014). A fire regime is defined as the frequency, season, intensity, and sizes of fires (Gill 1975). Anthropogenic fires are typically more frequent, early-season, low-intensity, and small-scale than wildfires (Archibald et al. 2013). In anthropogenic fire regimes, ungulate herbivores typically reduce standing fuels by consuming a large share of annual biomass production. Remaining surface fuels are then typically removed by frequent controlled early-season patchburning (Laris and Wardell 2006, Archibald 2016). This traditional fire management practice typically creates an ignitionsaturated, fuel-limited fire regime, in which fire size and intensity is regulated by fuel quantity, quality, and spatial distribution (Pausas and Fernández-Muñoz 2012, Pausas and Keeley 2014). Frequent anthropogenic ignition over long time periods often created a more fine-grained landscape mosaic structure, because recently burnt patches are nonflammable until surface fuels have rebuilt (Baeza et al. 2011, Johansson and Granström 2014). In shrublands this can take several years, and in such cases young stands act as fuel-breaks in the landscape, limiting the size of consecutive fires (Minnich and Chou 1997, Allen 2008, van Wilgen 2013, Johansson and Granström 2014).

\section{Fire regime shifts}

Fire regime shifts have occurred several times in geological time scales, e.g., in response to increased atmospheric oxygen (Bowman et al. 2009) and the evolution of flammable grasses (Pausas and Keeley 2009, Strömberg 2011, Bond and Midgley 2012). When

${ }^{1}$ Department of Ecology, Environment and Plant Sciences, Stockholm University, Stockholm, Sweden, ${ }^{2}$ GEMS Center, University of Minnesota, USA, ${ }^{3}$ Department of Physical Geography, Stockholm University, Stockholm, Sweden, ${ }^{4}$ Center for International Forestry Research (CIFOR), Sustainable Landscapes and Livelihoods Research Team, CIFOR Nairobi, Kenya 
humans first arrived, dramatic increases in ignition frequency occurred, because of the need for open landscapes containing more food resources (Bowman et al. 2011). Also megaherbivore extinctions likely altered fire regimes globally (Johnson et al. 2018). Today most flammable biomes are experiencing the reverse trend; a rapid decrease in ignition rates (Bowman et al. 2011, Archibald et al. 2013). One example is fire suppression in Mediterranean-type forests, often causing fuel accumulation and increased fire intensity and size (Williams 2013, Pausas and Keeley 2014). Apart from burn bans, there are many socioeconomic changes that may cause fire-regime shifts, e.g., abandonment of traditional land management due to population growth (Butz 2009), agricultural intensification, rural depopulation, or nature conservation (Pausas and FernándezMuñoz 2012, Pausas and Keeley 2014). Where traditional fire management has been terminated, fire regimes typically have shifted into ignition-limited fire regimes characterized by longer fire intervals, more surface fuels, higher fire intensities, and larger fires (Williams 2013). This has been directly observed mainly in the northern Mediterranean basin, where it happened quite recently (Pausas and Fernández-Muñoz 2012). Other shrub systems have also been traditionally managed by fire, e.g., the Californian Chaparral, but this prehistoric management terminated earlier and is less well understood (Keeley 2002, Anderson and Keeley 2018). The increased frequency of extreme fire weather due to climate change is also altering fire regimes globally, and this has large implications on current management options (Keith et al. 2014, Pausas and Keeley 2014, Dass et al. 2018).

\section{Fire suppression}

General burn bans, deriving from the Central European antifire paradigm (Pyne 1997, 2016), were during colonial times implemented across Africa, based on the assumption that fire degrades ecosystems (Pyne 1997, Laris and Wardell 2006, Archibald et al. 2012, Neumann 2014). In African grassy biomes, burn bans from the 1970 s typically resulted in pasture degradation, bush-encroachment, and biodiversity loss (Angassa and Oba 2008, Parr et al. 2014, Archibald 2016, Khatun et al. 2016). In South African fynbos, fire-suppression since the 1930s has threatened many species adapted to specific fire-return intervals (van Wilgen 2013). The East African ericaceous belt has likely been influenced by fire ever since it expanded after the last glacial retreat $\sim 14 \mathrm{ka}$ BP (Wesche et al. 2000, Umer et al. 2007, Schüler et al. 2012, Gil-Romera et al. 2019). Early land use history in the East African heathlands is largely unknown, as well as the effects of decades of fire-suppression. However, large wildfires have become increasingly problematic in protected heathland areas (e.g., Wesche et al. 2000, Hemp 2005, Belayneh et al. 2013). The importance of anthropogenic fire in shaping the East African ericaceous belt has been discussed (Hedberg 1964, Wesche et al. 2000, Jacob et al. 2015), but rarely from an ancient cultural landscape perspective.

\section{Aims and objectives}

Land use change and climate change are two major threats to ecosystem resilience and productivity today. Occurring simultaneously, they interact across landscapes and potentially reinforce each other. International policies for climate mitigation through forest restoration, such as REDD+, have many times become a threat to fire-adapted ecosystems (Parr et al. 2014,
Khatun et al. 2016). Carbon forestry projects typically aim for total fire exclusion and grazing restrictions to promote tree regeneration, without assessing the associated risk of surface fuel accumulation (Barlow et al. 2012). There is a lack of ecological studies of still active anthropogenic fire regimes in flammable shrublands, because such systems are globally rare today. Bale Mountains is a unique social-ecological system in that the subalpine heathlands have been maintained by traditional fire management for thousands of years. Despite large fluctuations in livestock and human populations, nature conservation efforts, and a 50-year burn ban, the traditional patch-burning and freerange grazing has continued until present. However, since the creation of the Bale Mountains National Park in 1969, parts of the subalpine heathlands have been subjected to a stronger enforcement of the fire-exclusion policy, making the study area particularly suitable for studies of landscape effects of changes in land management.

The major aim of this study was to increase our understanding of how changes in policy and local land use has altered the fire regimes. Specifically we ask if and how the fire regimes have been affected by the creation of the Bale Mountains National Park, in comparison with similar, but less protected heathland areas outside the park. We compared remotely sensed images from inside and outside the park from 1968 to 2017 and analyzed interviews with 41 local agropastoralists. Our aim with the interviews was to obtain answers to the following questions: (1) How has fire management changed historically? (2) What are the differences in management between the park and outside? (3) What are the underlying causes of historical changes? (4) What is the traditional ecological knowledge regarding heathland fire ecology and fire management? Our hypothesis was that fires inside the park have become fewer but larger, because of the stronger fire-exclusion efforts, which leads to reduced numbers of nonflammable young stands acting as fuel-breaks in the landscape. In this paper we analyze drivers for change, and discuss how the traditional fire knowledge can be used as a base for developing a sounder, community-based fire-management program in order to conserve the unique ecosystem and at the same time adapt to climate change. Results from this project has implications for biodiversity conservation, local livelihoods and heathland management policy, given both climate change predictions and the new carbon sequestration ambitions.

\section{METHODS}

\section{Study area}

The Bale Mountains in the southern highlands of Ethiopia harbors the largest area of subalpine ericaceous vegetation in Africa ( 90000 ha, out of which the heathlands compose $\sim 70000$ ha), and harbors many threatened and endemic species (Miehe and Miehe 1994, Fetene et al. 2006). The Bale Mountains National Park (BMNP) was established in 1969 to protect the unique Afroalpine and montane forest habitats (Hillman 1988). This study focuses on the heathland zone ( 3500-3900 m.a.s.1.) inside and outside the park in an area of $\sim 95 \times 40 \mathrm{~km}$ (centered at $6^{\circ} 53^{\prime} 42.65^{\prime \prime} \mathrm{N}, 39^{\circ} 32^{\prime} 24.08^{\prime \prime} \mathrm{E}$; Fig. 1).

Out of the total heathland area, $69 \%$ is located within the park, and $31 \%$ outside, partly in the Adaba-Dodola forest priority area to the west. All areas are since 2013 included in the Bale 
Fig. 1. (a) Map of the study area in Bale Mountains (Sentinel-2 satellite imagery shown in NIR-RedGreen band composites, 10 March 2017); Bale Mountains National Park border (white line), heathland zone between $\sim 3500-3900$ m.a.s.1. (yellow lines). (b) Location of the study area in Ethiopia. (c) Climate diagram for 3400 m.a.s.1.

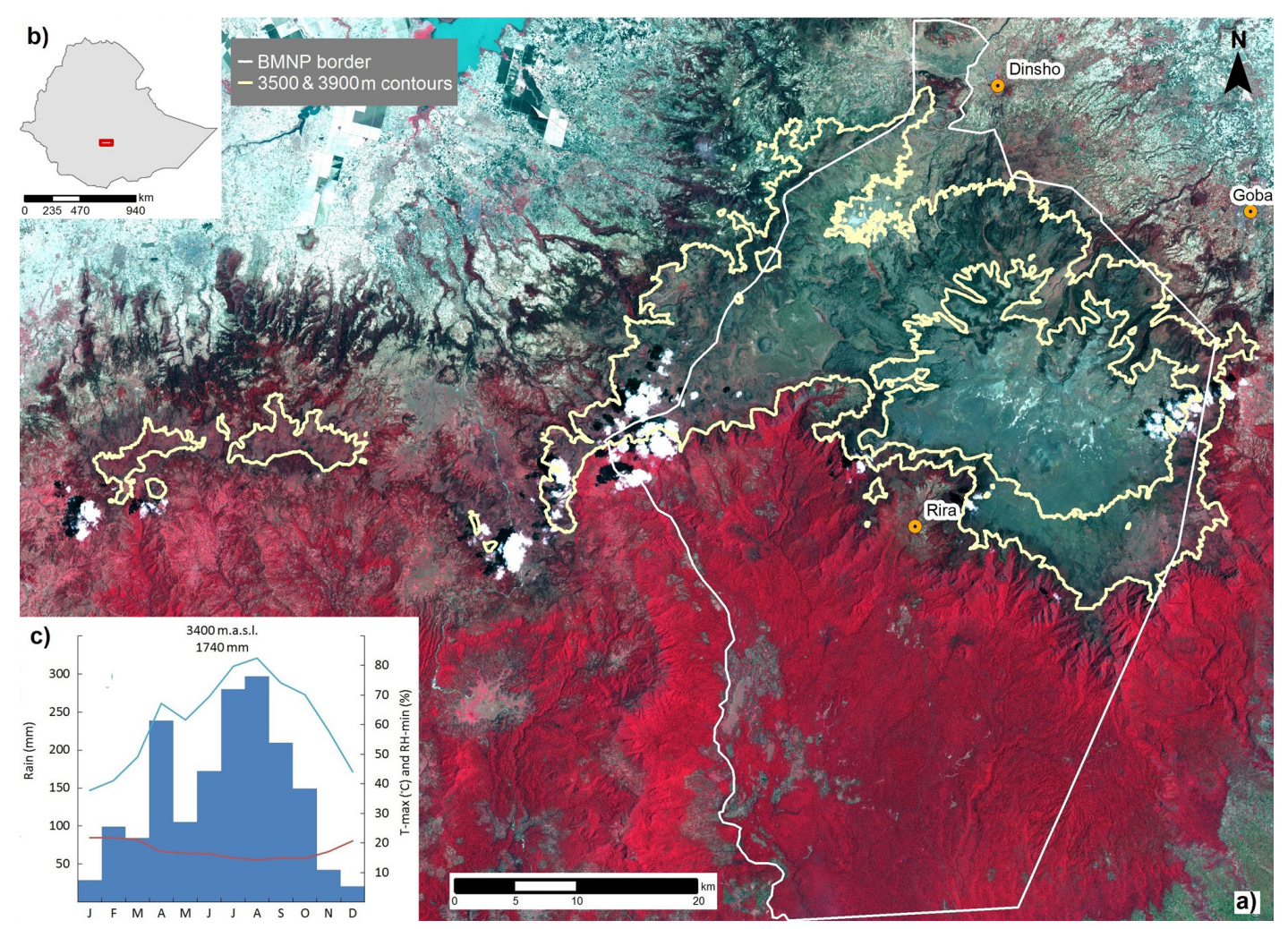

Mountains Eco-region REDD+ project. The project aims to conserve biodiversity and sequester carbon by increasing the enforcement of fire exclusion and grazing restrictions, including in the heathland zone (Watson et al. 2013, Oromia Forest and Wildlife Enterprise 2016). A brief background of geology, climate, vegetation, and land use history is important for understanding the social-ecological system (Appendix 1.1). The heathland vegetation comprises two codominating tree-heather species, Erica arborea and Erica trimera (Miehe and Miehe 1994), hereafter collectively referred to as Erica. Both species have potential to grow into tall trees, but when exposed to recurrent fire, they develop subterranean lignotubers and a multistemmed growth-form favorable for fire propagation (Johansson and Granström 2014). The heathlands are burnt on short rotation by local herders to improve pasture for free-ranging cattle (Johansson et al. 2012). They therefore consist of a mosaic of vegetatively regenerating Erica stands of different canopy age (time since last fire). This shifting patch mosaic favors a high biodiversity and creates extended habitat for Afroalpine plants (Johansson et al. 2018). Burning is done in the dry season (normally December-February, in drought-years extending into April). Erica stands rarely reach more than 2-3.5 m height ( 1630 years age) before being burnt again. Recently burnt stands appear black until the next rainy season because of the charred top soil (Fig. 2a). Young stands (1-3 years) are characterized by a grass/herb-dominated lawn in between resprouting large old
Erica lignotubers (Fig. 2b). The grass lawn cures in the dry season and young stands appear yellow in remote-sensed imagery. Wild and domestic grazers/browsers prefer the young stands where they consume grass, herbs, and young Erica shoots (Evangelista et al. 2007, Gustafsson 2009). Stands younger than five years cannot burn because of lack of fine dead fuels, and therefore act as fuel breaks in the landscape (Johansson et al. 2012, Johansson and Granström 2014). From 5-8 years, the evergreen Erica shrub canopy gradually closes (Fig. 2c) and flammability increases with age because of fuel accumulation and the flammable nature of the Erica shrubs. Mature, 8-15 year old stands are easily ignited and burn in high-intensity crown fires, also under moderate drought (Johansson et al. 2012). From 15-16 years, stand flammability gradually decreases because the flammable shrub canopy starts to vertically separate from the surface fuels beneath (Johansson et al. 2012; Fig. 2d).

All land is state owned, but traditional user rights apply to grazing land (Bekele 2003, Tesfaye et al. 2012). Burning of all vegetation has been banned nationally since the mid-1970s according to the forest law (the law literally translates to "destruction of forests"; Bekele 2003, Angassa and Oba 2008). In the Bale Mountains the degree of enforcement of the burn ban and grazing restrictions has varied over time, both inside and outside the park (Abera and Kinahan 2011). Generally, burn-ban enforcement has been stronger inside the park, even though the exact location of the 
park border is unknown on the ground. The park is so large that enforcement has been efficient mainly near the roads (Abera and Kinahan 2011). There is large variation in the total area burnt in different fire years (Abera and Kinahan 2011, Johansson et al. 2012, Belayneh et al. 2013). This depends mainly on dry-season weather, the amount and spatial distribution of mature, burnable, stands, and the ignition frequency. Extreme fire years in Bale Mountains largely coincide with regional prolonged droughts due to ENSO-related short-rain failures in March-April (Jury 2016, Zeleke et al. 2017; see Table A1.1). These have been frequent the last two decades (Sass-Klaassen et al. 2008, Mokria et al. 2017). In extended drought years, the numbers of burnt patches accumulate throughout the prolonged dry season until April. Potential natural fuel-breaks like mires (diameters $\sim 10-400 \mathrm{~m}$ ), rocky outcrops, and patches of less flammable shrub species (Alchemilla and Helichrysum) are small and cover $<10 \%$ of the landscape (Fig. A1.1a).

Fig. 2. Bale Mountains heathland postfire succession: (a) a recently burnt stand with charred soil and dead Erica stems ( $\sim 50 \mathrm{~cm}$ tall) protruding from large lignotubers $(\sim 50-150 \mathrm{~cm}$ diameter) embedded in the humus layer; (b) a two-year-old nonflammable stand (new Erica stems $\sim 20 \mathrm{~cm}$ ) dominated by a hard-grazed lawn that cures and turns yellow in the dry season; (c) a highly flammable seven-year-old stand $(\sim 120 \mathrm{~cm})$ with closed evergreen Erica canopy; (d) 30 year old "overgrown" stand ( $\sim 3.8 \mathrm{~m}$ tall), still flammable, but needs more extreme weather to burn because the flammable canopy is vertically separated from surface fuels beneath.

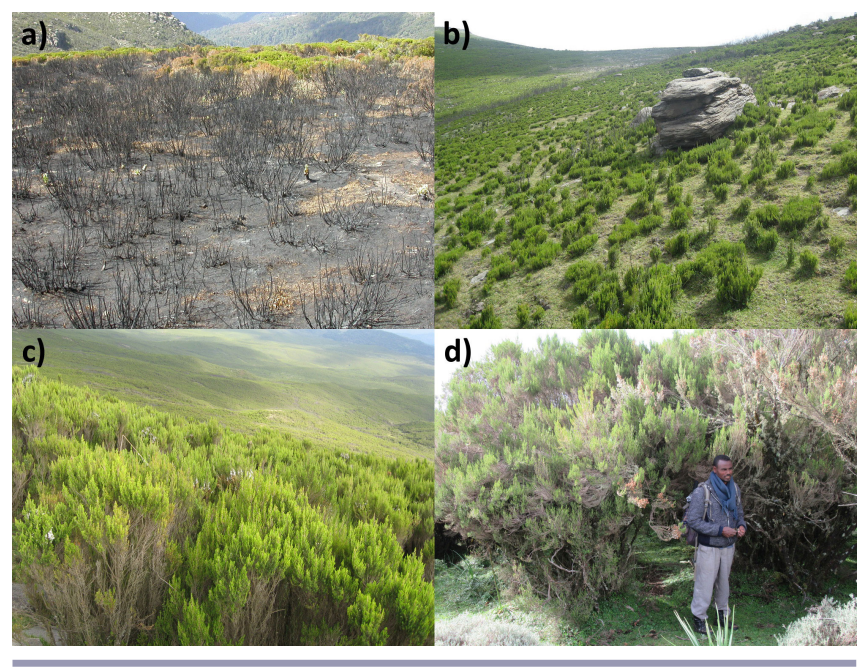

\section{Image analyses}

To quantify patch size change, aerial photos from 1968 and 1984, Landsat images from 1973, 1986, 2000, 2015, and 2017, and SPOT images from 2000, 2006, 2008, and 2011 were used (Table A1.2). To have a clear definition of fire year, our search-window started 1 January (aerial photos from December 1967 were assigned to fire-season 1968). The end of the search window was set to April to include prolonged droughts, but no images were found after February in any year. We selected all available cloud-free images spaced out over the 50-year period, but for the 1990s no cloudfree images were available for the park area. Thus, the 1995 data is not included in analyses. Aerial photos were scanned and georeferenced using ground control points (GCPs) in ArcGIS because interior orientation parameters were unavailable. Stand areas in these images are therefore not corrected for slope, which means that stands on steeper slopes $(\max 35 \%)$ are slightly underestimated in size, but these are rare and assumed to not affect the results. For further information on data handling see Appendix 1.2. The study area was limited to the heathland zone between 3500-3900 m.a.s.1. (Fig. 3). One large area of atypical land-cover was excluded (an area with large lava-flows, restricting fire movement), grasslands and Alchemilla spp. vegetation in the northwest of the park, and a small area of alpine vegetation in the southwest). We also excluded a $4 \mathrm{~km}$ wide buffer zone around the park border because the exact border location is unknown on the ground. For ground-truthing of stand age classes (see Appendix 1.3), landscape transects with GPS points on stand borders were collected inside the park in June 2018. For outside the park we used previously collected $(2016,2008,2007)$ GPS points. Sample points for patch size quantification were randomly selected for each year using a 500-m grid system (Fig. 3, Appendix 1.2).

Borders of each individual Erica stand patch (resulting from one separate fire event) were manually traced using ArcMap 10.0 (ESRI 2011; cf. Allen et al. 2016). Manual delineation of patches was necessary because automatization proved to be inaccurate for several reasons: (1) sedge-dominated mires optically resemble young grass-dominated Erica stands, (2) background knowledge of how fires are ignited and move in the landscape (normally better uphill) was necessary to correctly interpret stand borders, (3) sometimes it was necessary to consult predated images or Google Earth historical scenes, and follow individual stands over time to correctly interpret patterns of hill-shadows etc.

Because of the tedious work of manually delineating borders, we decided to do many point sample replicates instead of a full interpretation and delineation of the whole landscape. This limited our landscape metrics to a statistical sample of patch sizes from each area and time, but did not allow us to calculate other types of spatial statistics across the whole areas such as, for example, connectivity between patches of similar age. From repeated field trips to the area, as well as information from local land users and remote-sensed imagery, we knew beforehand that young stands were dispersed across the landscape, albeit varying in size. Therefore we focused the study on young stand patch sizes, and the proportion of young stands in the landscape, because these are the most important metrics for our main study question: consecutive fire size.

Image resolution differed between years, but in order to most correctly interpret border patterns, and to avoid losing information, we aimed at using the highest available resolution for each year, with minor resampling of most images to keep most images within the same spatial resolution. Images with lower resolution would by necessity have less accurate estimates of sizes, but we believe any systematic error from our resampling of the images used at two instances of the spatio-temporal analysis is kept to the minimum because the highest resolution images were not necessarily from just one end of the time frame as it is the case in most temporally varying imagery datasets. This is because the earliest images were also of high resolution that match the 
Fig. 3. Gridpoint sampling in the Bale Mountain heathland zone between 3500-3900 m.a.s.1., excluding atypical areas dominated by lava flows, grasslands, and alpine vegetation, and a 4-km wide buffer zone around the park border. Sample points centered in every 500-m pixel, blue outside and orange inside the Bale Mountains National Park. New points were randomly selected for each sampled year.

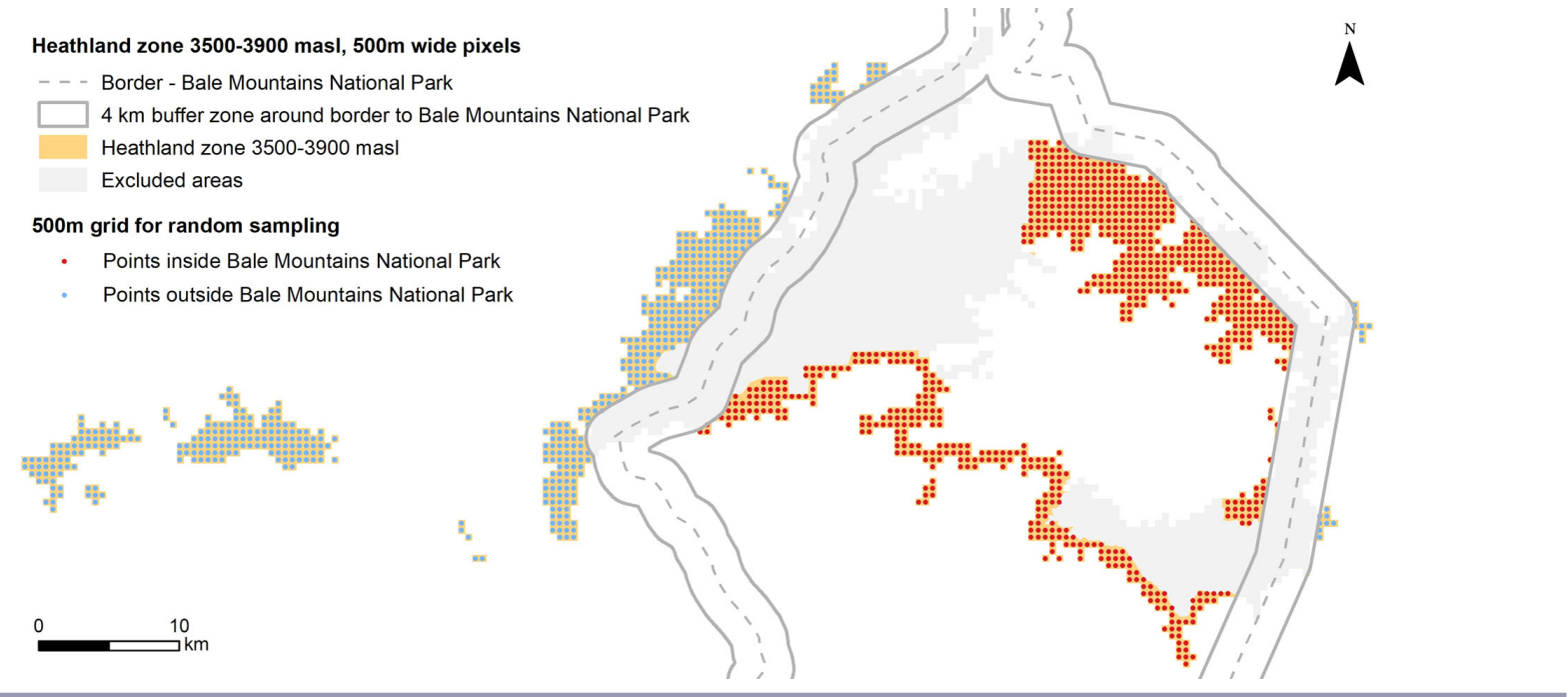

resolution of the images from later years (those accessed through SPOT; see Appendix 1.2).

In all images, the borders between recently burnt, black ( $0-1$ year), or young yellow (1-3 years), and mature green ( $>4-5$ years) stands were clearly visible (Fig. 4). A few cases of intermediate color were classified as "uncertain age" because these could be either 4-year-old stands, or older stands on flat land with sparse lignotubers. In such cases we used predated images to follow stand history. "Uncertain age" stands were excluded from final analyses. Borders between mature stands of different age were less clearly visible, as confirmed by ground truthing, and therefore we might have a general overestimation of mature stand sizes. Mature stands are not included in statistical analyses. Initially, patch size data was also grouped into confidence intervals (high confidence $=64 \%$ ), but preliminary analyses showed the same results when using all patches, so the presented statistics and graphs are done using all delineated burnt and young stands. Out of the total 1011 randomly sampled points, $65 \%$ hit Erica stands, out of these $48 \%$ were mature, $8 \%$ of uncertain age, $38 \%$ young, and $6 \%$ recently burnt stands. Proportion of points hitting Erica stands, other vegetation types, and different landscape features in each year is shown in Figure A1.1a. Total area cover of Erica stands in each successional stage is shown in Figure A1.1b.

\section{Flammability threshold age}

Grazing pressure is generally lower inside the park (Vial et al. 2011). Therefore Erica postfire growth might be slightly higher. Also, the southern slope dry season is slightly shorter and Erica postfire growth rates higher $(\sim 1 \mathrm{~cm}$ higher per year, personal observation). Therefore Erica stands could potentially become flammable earlier than the minimum 5 year age previously shown for outside the park on the northern aspect of the massif (Johansson et al. 2012). To confirm that the 5-year minimum age for flammability applies also inside the park and on the southern aspect, we analyzed pairs of satellite images, dated 1-2 years
Fig. 4. Examples of heathland stand borders in images: (a) from fire-year 1968, in the upper-left center, one light-colored young (1-3-year-old), irregular $\sim 80$ ha stand with clearly visible borders (with two small mature areas at the center-right, which at the time of fire were too young to burn); (b) the same area in 2017 showing one larger ( 170 ha) young stand, with three small mature stands inside (the road was built in the early 1980s); (c) from fire-year 1968, several light-colored young and dark mature stands ( $\sim-60$ ha) with distinct borders. To the upper right, a large young and a large mature stand on flat land with more widely spaced lignotubers (d) the same area in 2008 , with many small ( $\sim 0.5-3 \mathrm{ha})$ and a few large (the largest $\sim 18$ ha) fresh black burns and many small young and mature stands.
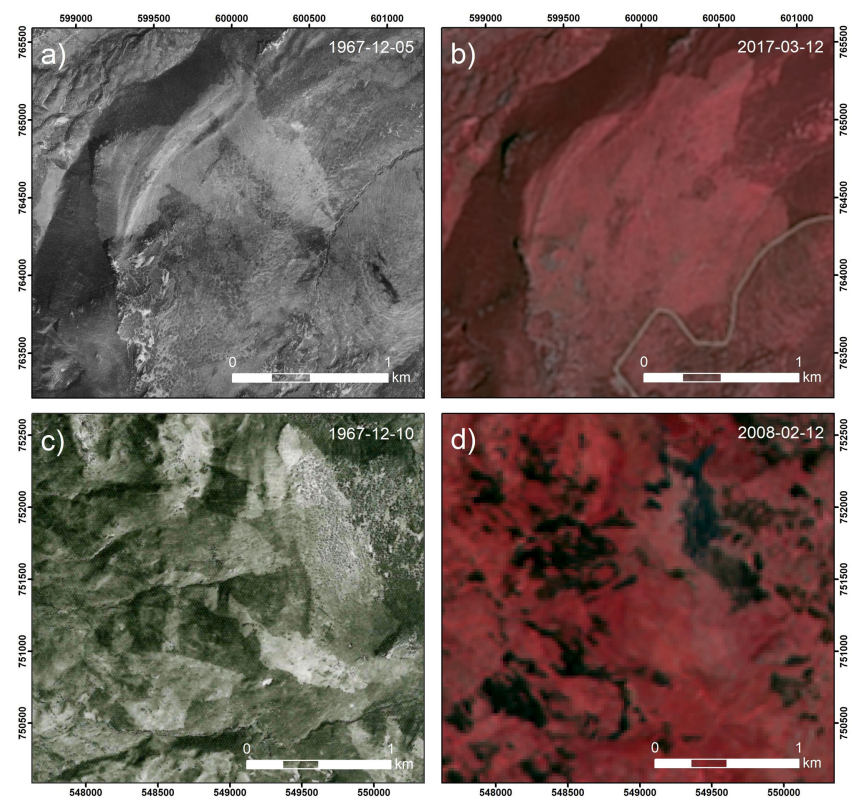
apart, to determine the prefire age-class of burnt stands. We used three pairs of images, 1999/2000, 2006/2008, 2015/2017, and for the later image we selected the delineated burnt-stand layer, and overlaid it on the 1-2 year predated image, and recorded the ageclass of the same patches. Using the time-difference between images, we calculated the preburn age of each burnt stand at the time of fire. None of the burnt stands were younger than 5 years old when burnt (Appendix 1.4, Table A1.3).

\section{Statistical analyses}

First, to test if the proportion burnt area had changed over time, and if this differed between inside and outside the park, we performed a linear model test, with year and site (inside/outside park) as explanatory variables and the proportion of points hitting burnt/young stands, compared to all points hitting Erica stands of all age-classes. This variable was arcsin transformed to meet assumptions of normality. All further analyses were done on stand patch sizes (log-transformed to meet test assumptions) of pooled burnt plus young stands, (excluding mature stands) to represent successive fire events over a three-year period before the image date. Four main tests were conducted: (1) to test if patch size changed as a consequence of the national park establishment, we run a linear model with patch size as the dependent variable and site (inside/outside park), year, and their interaction, as explanatory variables; (2) patch size change over time was tested for the park and outside separately by linear models with patch size as the dependent and year as the explanatory variable; (3) number of large patches ( $>100$ ha) was tested separately with the same linear model, with patch size as the dependent variable and site, year, and their interaction as explanatory variables; and (4) minimum stand age at time of fire (Appendix 1.4) was tested by the probability for young and mature stands to burn by Pearson's Chi-squared test with Yates' continuity correction data. For all analyses we used the statistical software R3.1 (R Core Team 2014) and studied residuals plots to evaluate if the models met the statistical assumptions.

\section{Interview methods}

Between May and June 2016 we conducted 6 individual, and 10 group interviews (with 2-4 persons) involving a total of 41 respondents, who are all members of local agropastoral communities and utilize the heathlands inside and outside Bale Mountains National Park. Respondents were selected with the help of village heads and the local interpreter. Interviews were semistructured and photo-aided in order to collect detailed information on forest and heathland utilization and management and traditional ecological knowledge on fire ecology and pasture management. Interviews were 1-2 hours long, directly interpreted from Oromo language to English, and also tape-recorded and transcribed by independent translators. We asked about historical and current policy changes through the establishment of the national park, the joint forest management project outside the park, and the new REDD+ project. Interview questions and photos are presented in Appendix 2. To understand the socialecological mechanisms behind heathland ecology and structure, and variation in burn sizes we specifically asked about ecological relationships, management goals and strategies, and historical changes in fire management. We asked for what they understand are the reasons behind the burn ban, their opinion on it, and if and how burn-ban enforcement has varied over time and space, and the effects of this. Specifically we sought answers to the following questions: What kind of fire management was practiced historically and today? What are the differences between inside the park and outside? What are the underlying causes of changes over the last decades? What is the status of the local traditional ecological knowledge regarding fire management? Questions were based on our previous knowledge about the system, mainly from outside the park (Johansson et al. 2012). There was high coherence between direct translation and audio transcripts. Respondents talked frankly about fire management, despite that heathland burning is illegal. Because of the qualitative nature of the questions asked, no quantitative analyses were done, but patterns of typical answers and exceptions were sought in relation to respondents' wealth class, age group, or residency (Table A1.5). The same Erica species dominate both the old tree heather cloud forest below the tree line, and the fire-managed heathlands (which would become forest, if unburnt for $>50$ years), and both zones are locally called Sato (meaning Erica). Therefore the heathlands were often referred to as "forest" in the responses.

\section{RESULTS}

\section{Empirical results}

The proportion of points hitting 0-3-year-old stands (burnt plus young stands pooled, Fig. A1.1.a) out of all Erica stands, had a tendency to increase over time, both inside and outside the park $(\mathrm{P}=0.051)$, but there was no consistent difference in the proportion 0-3-year-old stands inside vs. outside the park, and no significant interaction. The main analysis showed that the variation in patch size of $0-3$ year old stands was explained by an interaction effect between year and site (inside/outside park; $\mathrm{P}=$ 0.010), indicating that the trajectories of patch size change since 1969 have been different inside vs outside the park (Fig. 5). In 1968 and 1973 the average patch size (back-transformed from means of logged values) of 0-3-year-old stands in the two areas were in the same order of magnitude ( 8 vs. 10 ha in 1968, and 29 vs. 27 ha in 1973, inside/outside park, respectively). However, in 1984 and 1987 average patch sizes were larger inside the park (21 vs. 5 ha in 1984, and 27 vs. 5 ha in 1987, inside/outside park, respectively). In the 2000 Landsat image and the 2008 SPOT image (Fig. A1.3b) few, but large, black burns are visible inside the park, while outside the park burns are many and small. The statistical models showed a tendency for patch sizes to increase inside the park $(\mathrm{P}=0.052)$ and a clear decrease outside the park $(\mathrm{P}<0.001$; Figs. 5 and A1.2).

Specifically, the largest fires ( $>100$ ha) have increased over time inside the park, but not outside ( $\mathrm{P}=0.019$; Figs. 5 and 6). Prior to the 1990s, large fires did not occur every sampled year, and when occurring numbers were 2 or less. After 2000, large fires occurred every sampled year, in numbers of 3-5 inside the park and $0-1$ outside the park. Ground photos of typical burn patterns are given in Figure 7a-b, and an enlarged section of the 2008 SPOT image is shown in Fig 7c.

\section{Interview results}

Responses regarding livelihood strategies and heathland management were similar inside and outside the park. Older respondents gave more details on historical trends. Population growth, cessation of seasonal migration, agricultural expansion, and increased droughts were the major changes the last 50 years. Wealth-class, age, gender, or proportion livestock income (Table 
Fig. 5. Jitter diagram of Erica stand patch sizes 1968-2017. Recently burnt stands (< 1 year old, filled symbols) and young stands (1-3 year old, unfilled symbols), inside (black $\diamond$ ) vs. outside (red o) Bale Mountains National Park (BMNP), established in 1969, (y-axis in $\log 10$ scale). Horizontal lines are the (back-transformed) averages of logged areas of the pooled Young+Burnt stands, error bars = 1SE. 1995 park data is missing because of cloud cover (1995 data not included in statistical analyses). Line diagrams at the bottom show the dry-season (Dec-April) rain data for Robe (34-year average as dashed line) and Addis Ababa (52-year average as dashed line).

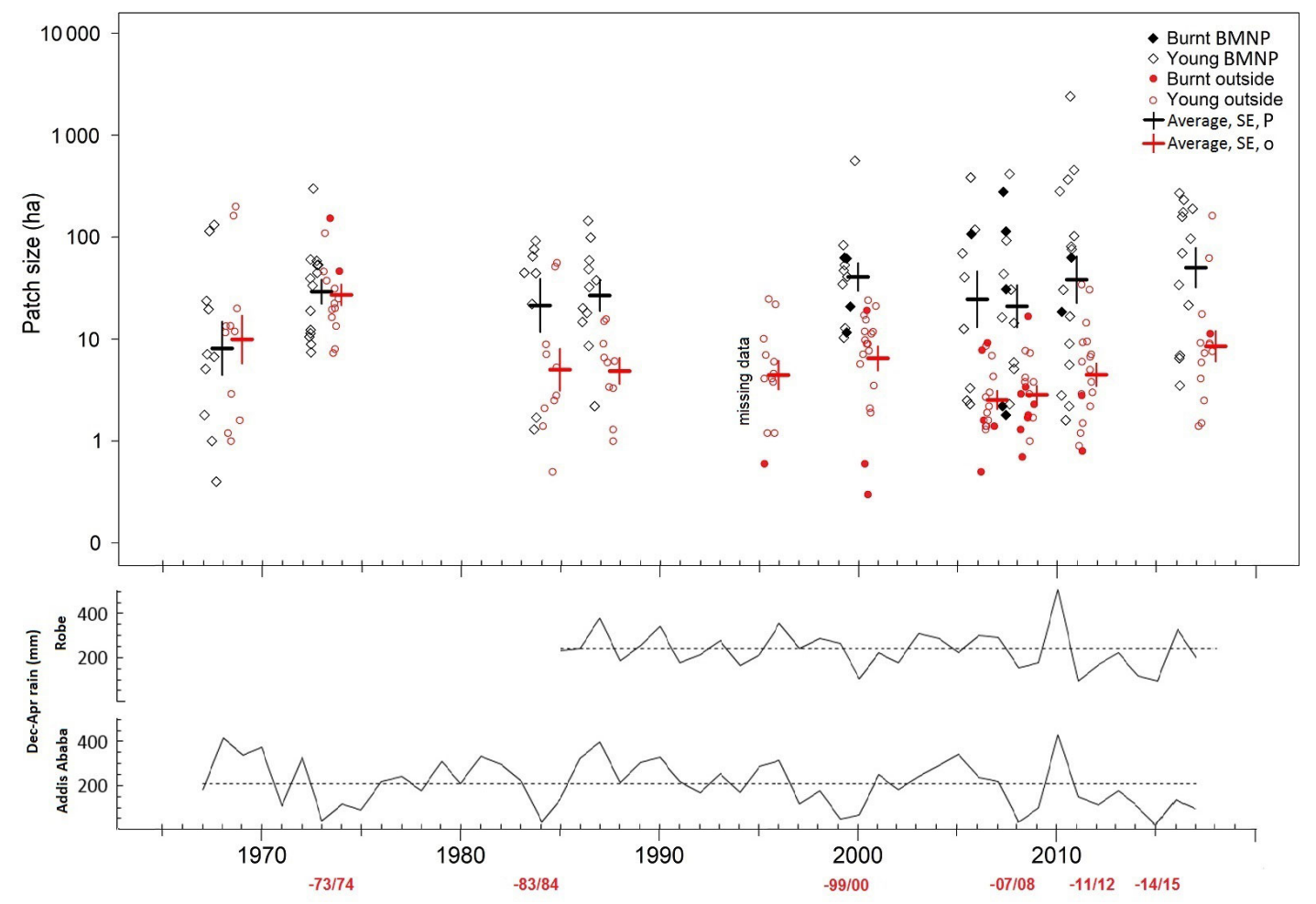

A1.5) had little influence on fire management knowledge or objectives, and responses were highly consistent. Respondents lived their whole life in the area, and their grandparents also lived there. Respondents from road-less villages on the southern aspect historically had less interaction with authorities and experienced less conflict regarding fire and grazing.

Fig. 6. Numbers of large fires ( $>100$ ha) inside and outside Bale Mountains National Park (BMNP) over time.

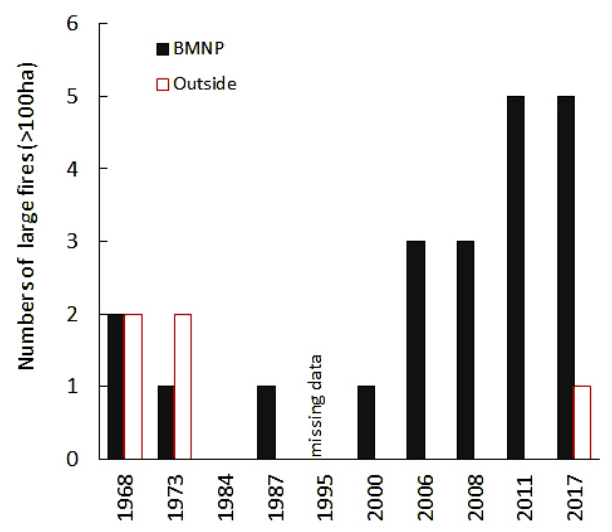

Local livelihoods depend on heathland burning

Old respondents said that 40 years ago all income came from cattle and honey, and they reared larger herds (some $>100$ cows) comprising cattle and horses only. Today respondents reported to own a maximum of 30 cows, 10 horses, and 30 sheep. Few respondents reported keeping goats or donkeys. All respondents depend on the heathlands for pasture, especially during the dry season when the forest grass cures.

All respondents said that without frequent burning, the heathlands would soon turn into a continuous tall shrub without any grazing value. Reasons for burning the heathlands were found to be the same inside the park as outside. The major objectives were to increase grass/herb production, to get rid of a harmful urticating moth caterpillar, and to minimize livestock loss to hyenas and leopards (cf. Johansson et al. 2012). The heathlands are also important for honey production. Local wild bees are reared in log beehives, placed in trees at the tree line, and many forest tree species also contribute nectar. Erica arborea was said to produce more nectar than Erica trimera, and short fire cycles favors $E$. arborea because it flowers and sets seed earlier (from $\sim 4$ years, compared to E. trimera that starts flowering at $\sim 11$ years). 
Fig. 7. Burn patterns: (a) ground image of small-scale patch burns outside the park in March 2012; unburnt stands were $<5$ years old (sizes of burns $\sim 0.5-5 \mathrm{ha}$ ); (b) ground image of a large "black-smoke" fire inside the park in February 2008 (photo credit Ian Fulton), when this ridge was covered by one continuous $\sim 8$-year-old Erica stand, and no young stands. The final size of this fire was $>2400$ ha; (c) example of typical patch sizes inside vs. outside the park border (yellow dashed line) in the SPOT image from 11-12th February 2008 (Fig. A1.3b). Inside the park, near the village and road at the lower right, black-colored new burns are large (33-287 ha). In inaccessible areas near the park border, burn sizes are smaller (0.1-35 ha). Smallest sizes and highest numbers of black patches are found outside the park border to the lower left.

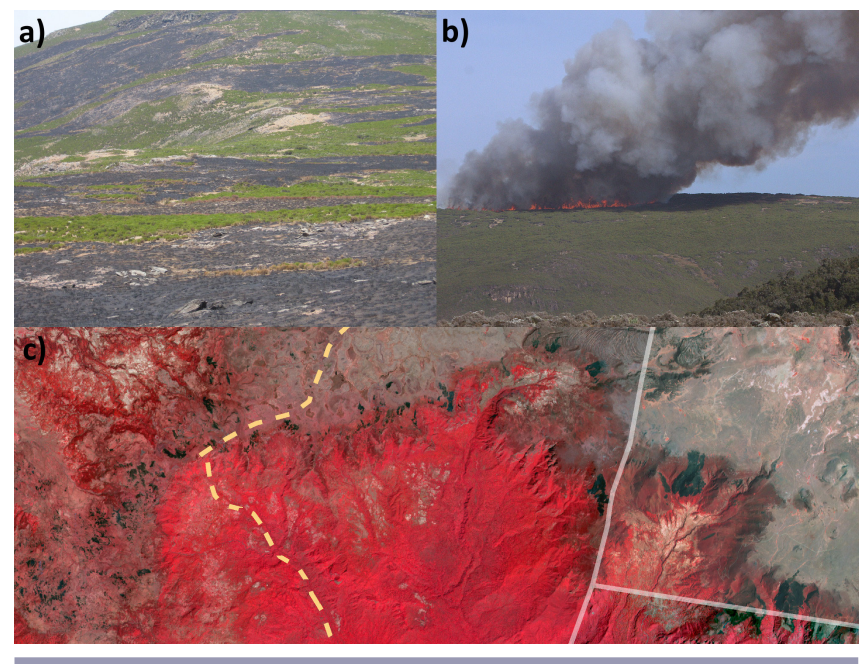

Agriculture accounted for up to $75 \%$ of household income and was dominated by barley, garlic, spring onions and cabbage. Livestock accounted for $10-90 \%$ of household income and this proportion was higher for older respondents. A few respondents earned a substantial share of their income from honey, bamboo, ecotourism, and park employment (Table A1.5).

\section{Historical change in fire management}

The objectives for burning were the same today as prior to park establishment. Because it's necessary they still burn, despite risking imprisonment. They said that eventually, if there was no fire for more than 50 years, the shrubs would grow into trees, but that this is unlikely to happen because complete ignition exclusion is impossible. Before the 1970s the fire management practice was different (Tables 1 and 2). Burning was done openly, and often collectively, by line ignition along the contour lines. Normally it was started earlier in the dry season: "As soon as the moss was dry, a group of men went out in the afternoon and ignited a mature stand in a somehow controlled way." First they made sure that no cattle or children were present by shouting Guba! (Fire!). Then several men simultaneously ignited many shrubs along a line at the down-slope border of a "mature" ( $~ 8-14$ years old) stand, in order to make an upslope high-intensity crown fire. Such, socalled guba qulquulo (clean fires), regular-shaped fires, consuming all shrub canopy within its borders, were preferred because they are perceived to produce better pasture and reduce the size of the remaining stumps, which restrict cattle access. Early-season fires normally produce white smoke (due to high water content of the foliage). Late-season fires produce black smoke (Fig. 7b) and these fires were referred to as "black-smoke fires." These are more common today, according to respondents, and were seen as destructive fires, mainly because they burn the soil. Today, according to respondents, ignition is not made in the best way. Now, especially inside the park because of the risk of being caught, ignition is often made later in the dry season. They explained that the reason for this is because it is easier to succeed with a quick-point ignition on the sly when the vegetation is very dry. This is often done by a single man passing on horseback, "“... just throwing a cigarette, or quickly igniting a single shrub when no one sees him." Some ignitions are today also purposely made late in the dry season because of conflict with the park, according to respondents.

Table 1. Summary of interview responses regarding general change in heathland management inside/outside Bale Mountains National Park (BMNP) since 1969 until present (2016).

\begin{tabular}{lll}
\hline \hline & Inside BMNP & Outside park \\
\hline Ignition frequency & lower & higher \\
Burn sizes & larger & smaller \\
Ignition timing & later in dry season & whenever possible \\
Grazing pressure & higher & higher \\
Pasture quality & lower & lower \\
\hline
\end{tabular}

Differences between inside and outside the park

Respondents said that fires inside the park have recently become larger and more dangerous, and exemplified this with the March 2015 fire in which one park staff was killed. They said that casualties never happened before. Though the park has some resources to patrol the heathlands, the area is too large to enforce the law everywhere and communities do not report ignition: "Because everyone needs pasture land, no one reports a burning incidence to the park." The risk of being caught igniting is higher near routes frequently patrolled by park rangers. The penalty for igniting is imprisonment with large penalty fees, both inside and outside the park. The park has more resources to control grazing and new settlements, but grazing pressure increases also inside the park, and new homesteads have been established above the tree line (Table A1.4). Respondents inside the park had in the past experienced more conflict with authorities, especially regarding burning and grazing. Some respondents also mentioned positive outcomes of the park, such as improved environmental protection and ecotourism. All respondents had an overall positive attitude toward the national park and the REDD+ project because they see the need for conservation and anticipate benefits from carbon trading and ecotourism. Relations between communities and the park has improved, with new benefits-sharing projects like schools, water, and electricity, but crop-raiding by wildlife from the park is also an increasing problem for the communities. Respondents also expected that they will be allowed to stay in their villages in the future. One respondent inside the park stressed the need to stay as follows: "If communities get money, they will manage the forest [including heathland] ... but if they get displaced from their village they would not want to receive even a billion birr, but they would choose to stay."Young respondents, especially 
Table 2. Summary of interview responses. Only responses held by all, or a majority of the respondents, are listed.

\begin{tabular}{|c|c|}
\hline Questions & Interview responses \\
\hline $\begin{array}{l}\text { Historical fire management } \\
\text { practice }\end{array}$ & $\begin{array}{l}\text { Ignition done openly, collectively by several men, by line ignition along the base of a mature stand } \\
\text { Ignition done as soon as possible (starting December-January) } \\
\text { Ignition done everywhere in the heathlands } \\
\text { Extended droughts rare } \\
\text { Late ignitions rare }\end{array}$ \\
\hline $\begin{array}{l}\text { Current fire management } \\
\text { practice }\end{array}$ & $\begin{array}{l}\text { Burning to increase pasture, to get rid of an insect pathogen, and to minimize livestock loss to predators } \\
\text { Inside the park, the enforced burn-ban has reduced ignition rates, reducing the numbers of fuel breaks } \\
\text { Because of the enforced burn-ban, ignition is done more secretly in areas out of sight, more so inside the park } \\
\text { Quick point ignitions on the sly, by single travelling men, or children } \\
\text { Quick ignition requires drier vegetation, and often occurs later in the dry season } \\
\text { Inside the park, also partly because of conflict, ignition is made later in the dry season } \\
\text { Outside the park increased ignition frequency has decreased fire sizes } \\
\text { Outside the park ignition is done whenever possible, also under intermediate fire-weather } \\
\text { Extended droughts common }\end{array}$ \\
\hline Historical changes & $\begin{array}{l}\text { Population growth, cessation of seasonal migration, agricultural expansion, increased droughts } \\
\text { Increased conservation efforts from authorities; national park, joint forest management project, REDD+ } \\
\text { Increased grazing pressure and year-round grazing in heathlands } \\
\text { Sheep and goats started grazing the heathlands, and these browse the Erica deeper down on the branches, and with a } \\
\text { larger bite diameter than cattle have } \\
\text { Decreased milk production per cow } \\
\text { Decreased honey production } \\
\text { Communal grazing land changed toward more "private" grazing land outside the park, occasional fencing and rental of } \\
\text { grazing land }\end{array}$ \\
\hline Local fire knowledge & $\begin{array}{l}\text { Burning essential for pasture, fire cannot be excluded } \\
\text { Less than } 10 \text { years of total fire exclusion would turn the heathlands into a continuous tall shrub with no grazing value } \\
\text { Without fire the heathland would eventually become Erica forest (after } \sim 50 \text { years), but this is unlikely because total fire } \\
\text { exclusion is unlikely } \\
\text { Stands younger than } ~ 5 \text { years cannot burn, because of lack of fine dead fuels, and this was the case also } 40 \text { years ago } \\
\text { Lack of young stands in the park make fires larger there } \\
\text { "Overgrown" stands cannot burn because of lack of moss layer and the vertical separation of canopy from surface } \\
\text { fuels } \\
\text { During extreme weather, fire might travel even in 5-year-old stands and "overgrown" stands, which normally do not } \\
\text { burn } \\
\text { Droughts have been frequent lately, but large fires occur mainly inside the park } \\
\text { Drought makes fires more destructive because of soil burning, which kills the Erica lignotubers } \\
\text { The Erica shrubs are important, as dry-season forage, to fuel fires, to prevent erosion, and to allow seed-set in grasses } \\
\text { and herbs } \\
\text { Respondents know in detail which herb/grass species are preferred by each animal species, despite not herding livestock } \\
\text { in the heathlands } \\
\text { The proportion grass has decreased and unpalatable herbs have increased because of overgrazing }\end{array}$ \\
\hline
\end{tabular}

outside the park, were aware of the concept of carbon storage, and said that they had been promised payments for planting trees (which some respondents had done, and were asking when payments will be made). Only one respondent, outside the park, received payments for forest protection. There was varied understanding of how REDD+ payments will work and whether it will benefit the communities or not, as indicated in the following quotes: "I didn't agree with carbon money because they may take our good forest and give us bad climate ... but if it doesn't have negative side-effects it might be a good idea." "Money paid for tree protection is good, but if cutting forest is totally forbidden it will be problem because then we will not be allowed even the stick we hold in our hand." "It is possible to protect our forest to store carbon ... it is good if they pay 800-1000 birr [ US\$27-34] per ha of pasture land." "It is a good idea to get money for protecting the forest because the reason for deforestation is also to get money." Outside the park, ignition frequency has increased since the 1970s, despite everyone knowing that it is illegal. Therefore, according to respondents, stand patches have become smaller. Grazing pressure has increased and is generally higher than in the park. Attempting to increase pasture production, men, and especially children, now ignite increasingly frequently, even under poor burning conditions. Children are often igniting because they cannot be put in prison, and ignitions increase during school breaks, according to respondents and observations. The new ignition practice with quick-point ignitions on the sly now also applies outside the park because burn-ban enforcement has recently increased on account of the REDD+ project.

Respondents said that lately the extended droughts occurred every 3-4 years, and that these make the fires more destructive, especially in the park. Some respondents explained that the reason behind increased fire sizes is primarily the lack of young stands that stop the fires. It appears that most respondents clearly 
understand that when few stands are burnt early-season or in poor fire years, the fires in drought years become larger. Another explanation according to the respondents, could be that during extremely dry and windy conditions, fire might travel even in 5year-old stands, and in old "overgrown" stands (Fig. 2d), which normally do not burn. Respondents said that young stands are impossible to burn, and old respondents said this was the case also when grazing pressure was lower when they were young. Respondents inside the park were worried that fires have become more dangerous and out of control, like the April 2008 fires when the park ordered helicopters, military servants, and school children to stop fires, at the same time as local youngsters were igniting down slope. Discussing a photo of this event, respondents said, "It is very dangerous, stopping fire in mature Erica is impossible" and "It is because of the conflict that someone was still igniting below." Respondents also emphasized the problem with soil fires, and that this was uncommon earlier. They said that late-season burning, when the humus is dry, should be banned because soil fires kill the Erica lignotubers. They said that the Erica is needed in the system, both as dry season forage, and to fuel the fires, which they assume rejuvenate the pasture. All respondents said that pasture quality and milk production per cow has declined, mainly because of increased livestock density, but also because of year-around grazing. In the past, the heathlands were not grazed in the rainy season because, according to respondents, the cold fog makes cows and children sick, and increases livestock loss to predators. Recently also sheep and goats started grazing the heathlands and they browse the Erica shrubs more intensely, and, according to respondents, this may eventually kill the Erica. Traditionally all grazing land, both above and below the tree line, was communal land, but lately many cattle owners outside the park started building fences to secure longer grass for their own livestock. This was seen as a benefit to the fence owner, but a problem for the community because it causes deforestation. Fencing pasture is illegal but, according to respondents, started following the joint forest management project outside the park. A new phenomenon in the last decade is that it is now possible to rent access to pasture land despite the fact that no grazing land is private.

\section{Local fire knowledge}

The traditional ecological knowledge regarding fire ecology and fire management is deep and widespread, both inside and outside the park (Table 2). Respondents could with high precision tell the postfire age of Erica stands in photos. They know that stands younger than five years old ("knee-height") cannot burn because of lack of fuels, and that 8-14-year-old stands ("waist-height") are "mature" and easy to burn, and when stands are taller than head-height, they are "overgrown" and need extreme dry weather to burn. They said, "The local community knows more than the agricultural office about fire." Only one respondent, who worked as a ranger, stated that burning is bad: "As we were trained by the experts, burning Sato is bad and causes mineral depletion ... and kills wildlife." But later he said that without fire there would be no pasture, and "the heathlands have been burnt since my grandfathers' time." The old men complained that children nowadays have little fire knowledge: "children make small dirty burns with messy borders ... full of green areas inside, or with large stumps." But they said that children on the other hand know other things that the elders don't know, for example, that the urticating caterpillar will become a moth. Fire management is a male task, nevertheless women also had detailed knowledge about fire ecology, burn practices, and ecological effects on pasture quality and cattle health. One old woman pointed out the fact that it is necessary to have "both young and old stands within daily walking distance of the cattle" to provide a continuous supply of young stands over time. Even though the cattle are not herded in the heathlands, most respondents were well aware of pasture ecology, for example, which herb species were preferred by different animals, and that the proportion grass cover had decreased and unpalatable herbs increased because of overgrazing. Some respondents mentioned the importance of the shrubs for protecting grasses and herbs, and preventing erosion. The respondents were interested in reaching a more constructive dialogue with the authorities on how to stop the dangerous lateseason fires, and also to solve the problem of overgrazing.

\section{DISCUSSION}

Our empirical results show that changes in policy and land use has altered fire regimes inside and outside the park in diverging directions. Before the creation of the park, heathland fire sizes were almost equal outside and inside the present park area. Since then, with some delay, fire sizes have decreased outside, but increased inside the park. Our interview results clarify the underlying mechanisms behind these trends: (1) burning is essential for local livelihoods and cannot be excluded from this highly flammable vegetation, (2) the more strongly enforced burn ban inside the national park has reduced ignition rates and hence the number of young stands acting as fuel-breaks, resulting in larger fires, (3) the burn ban has shifted ignitions to later in the dry season, (4) outside the park increased ignition, caused by intensified land use, has decreased fire sizes, and (5) extended droughts have been frequent lately, but large fires occurred mainly inside the park (Fig. 8).

\section{Mechanisms controlling patch size}

Despite the burn ban, there was no decrease in total burnt/young area in the park, but instead an increase. Three factors control fire sizes in the study landscape. The first is related to the mosaic structure of young stands in the landscape, resulting from preceding decades of ignition (cf. Minnich and Chou 1997). Second, there is often large interannual variation in fire frequency because of variation in dry season weather (cf. Seydack et al. 2007). The Bale heathland climate is normally extremely moist, and fire is normally possible only between December and February. In poor fire years only a few fires occur, and then mainly outside the park. In good fire years, fires are many, both inside and outside the park, but they become larger inside the park. The third factor is the ignition frequency. Anthropogenic ignition is, in this case balanced between local needs to produce food, and the official fire-suppression policy (cf. Pyne 1997, Laris and Wardell 2006, Kull and Laris 2009). Outside the park ignitions were frequent, even under poor burning conditions in bad fire years, as described in interviews and observed in the field. This could explain the few, small fires found outside the park only in poor fire years (Fig. 5).

\section{Shifted timing of ignition}

Our images were dated from (December)/January to February, hence the recorded burnt stands do not include late-season March-April fires in drought years. Late-season fires are instead 
Fig. 8. Conceptual diagram of changes affecting fire sizes inside and outside Bale Mountains National Park between 1969 and 2018. Main causal mechanisms in black solid lines, coinfluencing factors in grey dashed lines, $\uparrow / \downarrow$ and $+/$ - signs indicating directions of change.

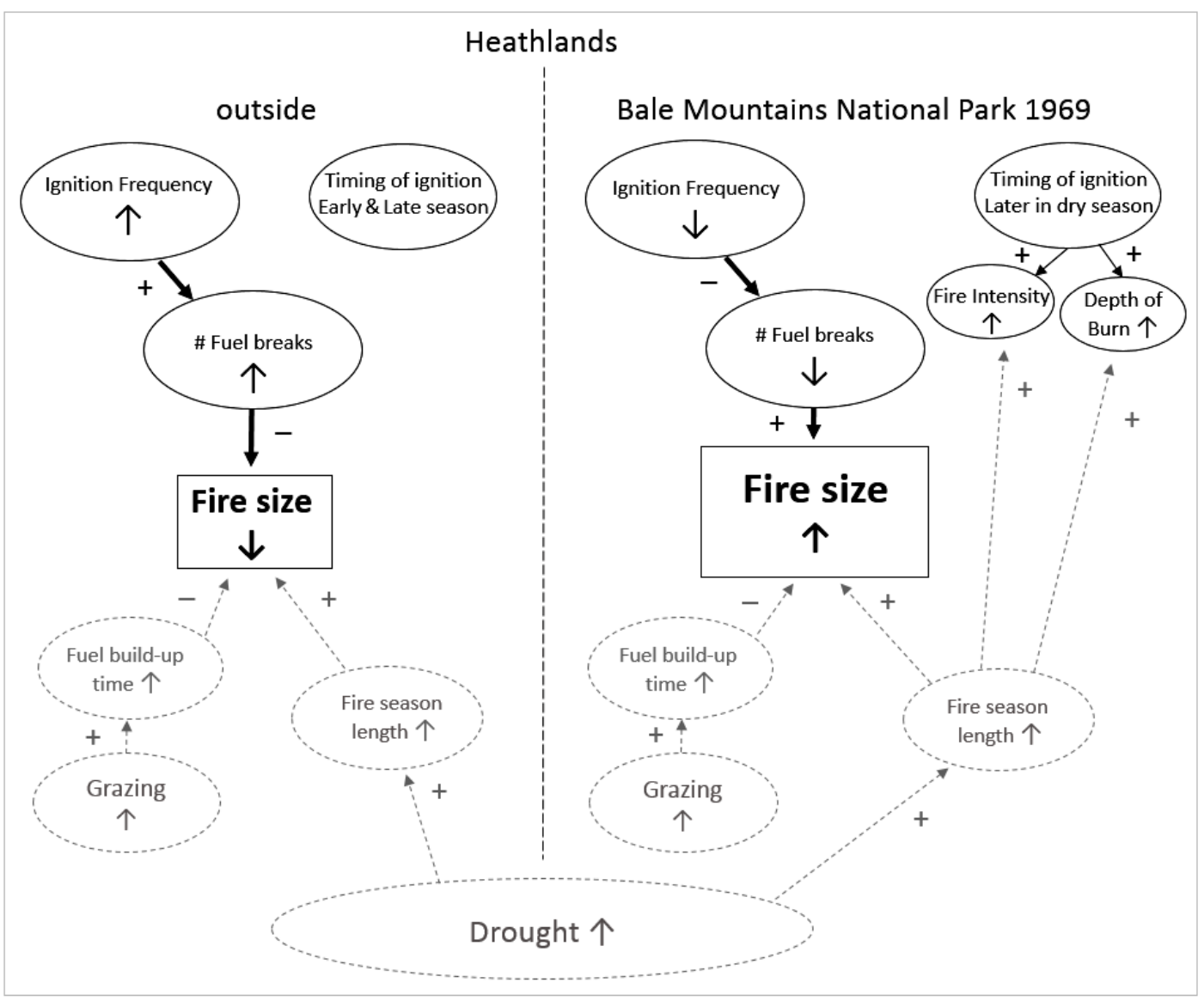

visible in the distribution of young stands 1-3 years later. For example the largest 2400 ha young patch recorded in 2011 , burned in April 2008 (which happens to be the black-smoke fire in Fig. 7b). Unfortunately our empirical data cannot quantify the shift in timing. But respondents stated that soil fires occur only during extended droughts, and these were rare in the past. This corroborates the fact that the heathland climate normally is very moist, and the humus layer rarely dries out (personal observation, between 2005 and 2016). The thick layers of accumulated humus, and the old age of the large E. trimera lignotubers (Johansson et al. 2012) also indicate that late-season smouldering humus fires have been rare in the past.

\section{Fuel breaks and the importance of livestock}

The patch-mosaic theory proposed by Minnich and Chou (1997) suggests that ignition saturation results in a fine-grained mosaic of young stands acting as fuel breaks in the landscape, exemplified by Mexican Chaparral. This requires ignition saturation, and that young stands really are nonflammable. This is not the case in the Californian Chaparral, where under extreme weather, fires burn through all age-classes, partly because of invasive annual grasses (Keeley and Fotheringham 2001, Brooks et al. 2004). In the Cape Fynbos, Seydack et al. (2007) showed that young stands were fuel- limited and did function as fuel breaks in the low-productivity drier proteoid shrublands, but not in the more productive alpine heathlands, which today are ungrazed. In Patagonia intense livestock grazing altered fuel composition and decreased shrubland flammability (Blackhall et al. 2017). In subalpine heathlands in Victoria, Australia, cattle were reported to have little effect on shrub fuels, because they avoided old stands (Williams et al. 2006). Apart from low site productivity, fuel limitation in young stands can also arise because of intensive range production where livestock consume large quantities of grass and shrub fuel, especially in young stands, as in Bale Mountains. Our results show that stands younger than 5 years do act as fuel breaks, but we do not know whether our 1-3 year old stands could potentially transfer fire if the grass was not grazed short. However, old respondents said that young stands also stopped consecutive fires 40 years ago, when grazing pressure was lower. Young stands are also intensively grazed by large populations of alpine rodents (Vial et al. 2011, Jira et al. 2013). According to our previous experiments (Johansson et al., unpublished data), a two-year-old fenced stand with $\sim 15 \mathrm{~cm}$ tall, not fully cured, grass stopped a fire in December 2008. 


\section{Biodiversity and prescribed burning}

In the Bale Mountains heathlands, cattle grazing, at moderate stocking density, is an important factor for the fire regime and for biodiversity. Cattle have probably grazed these heathlands since anthropogenic burning started, at least 2000 years ago (GilRomera et al. 2019). It is the combination of patch burning and grazing that created this species-rich landscape, and both are necessary for maintaining its resilience.

We did not quantify other landscape metrics than stand size and the proportion of young stands because of methodological constrains (see methods). However, it could have been interesting to compare other spatial characteristics such as mean distance between patches of similar age. Yet, based on qualitative impressions from the imagery and from the field, it is quite clear that small fire sizes also lead to a mosaic pattern with shorter mean distances between patches of similar age.

Young stands provide habitat for many Afroalpine plants (Johansson et al. 2018) and also to grass-eating rodents, important prey for the Simien Wolf (Canis simensis; Vial et al. 2011). Conservationists have not yet embraced the concept of high biological values of cultural landscapes in Africa (Neumann 2014). This has caused conflicts in many national parks regarding fire and grazing (Neumann 1998). We argue that, just like European heathlands, the Bale Mountains heathlands should be understood as an ancient cultural landscape, and managed in the traditional way, but science-based, legally, and controlled.

The reintroduction of patch-burning as a tool for shrubland fuel reduction and/or biodiversity conservation has been controversial (Bradstock et al. 1995, Russell-Smith et al. 2002, Allen 2008). Recently burnt open stands provide habitat to different herbaceous communities than old shady stands (Rundel 1998, Wesche 2006, Allen 2008, Johansson et al. 2018). Hence prescribed burning can increase biodiversity, if young stands are rare in the landscape. But if old stands are rare and harbor threatened species, burning can reduce biodiversity (Bradstock et al. 1995, Syphard et al. 2019). Optimal management should depend on the historic fire regime under which current plant communities assembled. Reintroduction of patch-burning (Fernandes et al. 2013) and livestock grazing (Lovreglio et al. 2014, Marques et al. 2017) has been successful mainly in the Mediterranean basin, maybe because of the short time span since their cessation. Prescribed early-season fires burning under mild fire weather can actually increase the abundance of old patches in the landscape because then they are less flammable (Murphy et al. 2015). Once the fine-grained landscape mosaic has been lost, it can be difficult to restore it in highly flammable vegetation because of the lack of young stands to burn against (Murphy et al. 2015).

\section{Prescribed burning as an adaptation to climate change}

In Bale Mountains, while land management diverged in two opposing directions over the last 50 years, climate change should also have influenced the fire regimes. As respondents pointed out, extended droughts have been frequent recently (also cf. Mokria et al. 2017, Mekonnen et al. 2018). This has four implications on the fire regime: a longer dry period to accumulate fires, more lateseason fires, reduced primary production increasing fuel build-up time, and the risk of smouldering soil fires killing the Erica lignotubers. Droughts affect both areas equally, but increased fire size has become a problem inside the park only. Outside the park intensified land use pre-emptied heathland fuels and thus potentially partly counteract some effects of climate change (Fig. $8)$.

\section{Traditional shrubland fire knowledge}

Our interviews showed that the traditional fire knowledge is still vivid, deep, and widespread among local communities. It is evidence-based, adaptive, and has evolved through long-term interaction with the heathland ecosystem. The contrast between the traditional knowledge and the enforced burn ban has caused confusion and conflict. Even though respondents were aware of the arguments behind the burn ban, they were unable to follow the law in order to feed their livestock. This has caused recurring conflicts, changed ignition patterns, and has resulted in larger fires. This, in combination with frequent droughts, has created a dangerous situation that both communities and authorities wish to end. Respondents emphasized that late-season burning should be stopped, and that this would be facilitated through a dialogue between the park and the communities on legalization and regulation of fire management. Misconceptions among authorities regarding traditional fire management have caused similar problems of fuel build-up and increased fire size and severity in, e.g., Australian savannas (Yibarbuk et al. 2001), Portuguese shrublands (Fernandes et al. 2013), and Brazilian Cerrados (Eloy et al. 2019). In Ethiopia, 10 years of almost total fire exclusion contributed to the exceptionally large heathland fire on Mount Kaka in 2012 (Ararsa Beyene, personal communication). Possibly some of the large heathland fires reported from other East African heathlands could also be partly caused by cessation of (largely undocumented) preceding traditional fire management.

\section{CONCLUSIONS AND MANAGEMENT IMPLICATIONS}

The main aim of this study was to increase our understanding of how changes in policy and land use has altered the fire regimes, and how this has implications for the new REDD+ project, and potentially also for other REDD+ projects in flammable ecosystems. Increasing land scarcity, conflicting goals, and fire exclusion has led to a situation of nonoptimal fire management. The fact that burning is illegal hinders the development of a sound fire management policy. Today the situation in the park is difficult, with increasingly large fires, in combination with recurrent droughts. But the prospective to develop a successful communitybased fire management program is better than in many other shrubland systems. The old Erica lignotubers have been resilient to a wide range of fire intervals, the stand structure is not yet completely homogenized, the traditional fire management knowledge is still present, there are no invasive fire-regime altering species, and the fire-weather is not as extreme as in other places. There is a genuine interest among communities to cooperate with authorities to develop an acceptable joint regulation of burning and grazing, as long as they are allowed to remain in the park. The park authority has acknowledged the ecological role of fire in the heathlands. There is a growing awareness of the necessity of science-based prescribed burning to increase long-term carbon storage and biodiversity in savanna systems (Teketay 2000, FAO 2011). Traditional fire management can be successfully integrated in climate mitigation projects. This was first tried in the West Arnhem Land fire abatement project in Australia (Yibarbuk et 
al. 2001). This concept has now been spread to, e.g., the Brazilian Cerrados (Eloy et al. 2019) and Botswana by The International Savanna Fire Management Initiative, which will continue giving practical workshops in Africa on joint fire management. In the face of climate change, it is necessary to adapt land management strategies in order to reduce wildfire risk (Dearing et al. 2010, Fernandes 2013, van Breugel et al. 2016). Attempts at short-term increase carbon capture, without a thorough understanding of the local social-ecological context of fire and grazing, can lead to large-scale wildfires, carbon loss, and ecosystem degradation in the long term. We suggest that REDD+ projects in flammable ecosystems first investigate the fire history and social context of the systems they aim to restore, and then adopt fire policy based on this, instead of initially enforcing blanket burn bans and grazing restrictions. We suggest that the Bale Mountains REDD+ project abandons the strict fire-exclusion policy, and instead develops a joint fire management program for the heathlands, agreed upon by all stakeholders. This should include prescribed early-season small burns, with varied rotation intervals, and a respected ban on late-season ignition, as well as grazing regulations. In developing this program there is a need to make use of the vivid local traditional fire knowledge, which is globally unique for a flammable shrubland system.

Responses to this article can be read online at: http://www.ecologyandsociety.org/issues/responses. $\mathrm{php} / 11260$

\begin{abstract}
Acknowledgments:
Many thanks to assistant Ayano Abraham who interpreted interviews and collected ground truthing data. Carl Frisk collected ground truthing data. Tadele Kifle transcribed interview audio files to English. Historical satellite images were acquired free of charge on a requisition grant from USGS. Brook Daniel assisted in acquiring and geo-rectifying aerial photos. CIFOR provided office space and support in Ethiopia. Helle Skånes provided GIS advice, Victor Johansson gave advice on figures, and Lowe Börjesson gave advice on qualitative interview interpretation and presentation.
\end{abstract}

\section{LITERATURE CITED}

Abera, K., and A. A. Kinahan. 2011. Factors affecting fire extent and frequency in the Bale mountains National Park. Walia 2011:146-157.

Allen, H. D. 2008. Fire: plant functional types and patch mosaic burning in fire-prone ecosystems. Progress in Physical Geography 32:421-437. https://doi.org/10.1177/0309133308096754

Allen, K. A., P. Denelle, F. M. S. Ruiz, V. M. Santana, and R. H. Marrs. 2016. Prescribed moorland burning meets good practice guidelines: a monitoring case study using aerial photography in the Peak District, UK. Ecological Indicators 62:76-85. https://doi. org/10.1016/j.ecolind.2015.11.030

Anderson, M. K., and J. E. Keeley. 2018. Native peoples' relationship to the California chaparral. Pages 79-121 in E. C. Underwood, H. D. Safford, N. A. Molinari, and J. E. Keeley, editors. Valuing chaparral: ecological, socio-economic, and management perspectives. Springer International, Cham, Switzerland. https://doi.org/10.1007/978-3-319-68303-4_4

Angassa, A., and G. Oba. 2008. Herder perceptions on impacts of range enclosures, crop farming, fire ban and bush encroachment on the rangelands of Borana, southern Ethiopia. Human Ecology 36:201-215. https://doi.org/10.1007/s10745-007-9156$\underline{z}$

Archibald, S. 2016. Managing the human component of fire regimes: lessons from Africa. Philosophical Transactions of the Royal Society B: Biological Sciences 371:20150346. https://doi. org/10.1098/rstb.2015.0346

Archibald, S., C. E. R. Lehmann, J. L. Gömez-Dans, and R. A. Bradstock. 2013. Defining pyromes and global syndromes of fire regimes. Proceedings of the National Academy of Sciences of the United States of America 110:6442-6447. https://doi.org/10.1073/ pnas. 1211466110

Archibald, S., A. C. Staver, and S. A. Levin. 2012. Evolution of human-driven fire regimes in Africa. Proceedings of the National Academy of Sciences of the United States of America 109:847-852. https://doi.org/10.1073/pnas.1118648109

Baeza, M. J., V. M. Santana, J. G. Pausas, and V. R. Vallejo. 2011. Successional trends in standing dead biomass in Mediterranean basin species. Journal of Vegetation Science 22:467-474. https:// doi.org/10.1111/j.1654-1103.2011.01262.x

Barlow, J., L. Parry, T. A. Gardner, J. Ferreira, L. E. O. C. Aragão, R. Carmenta, E. Berenguer, I. C. G. Vieira, C. Souza, and M. A. Cochrane. 2012. The critical importance of considering fire in REDD+ programs. Biological Conservation 154:1-8. https://doi. org/10.1016/j.biocon.2012.03.034

Bekele, M. 2003. Forest property rights, the role of the state, and intitutional exigency. Dissertation. Swedish University of Agricultural Sciences, Uppsala, Sweden.

Belayneh, A., T. Yohannes, and A. Worku. 2013. Recurrent and extensive forest fire incidence in the Bale Mountains National Park (BMNP), Ethiopia: extent, cause and consequences. International Journal of Environmental Sciences 2:29-39.

Blackhall, M., E. Raffaele, J. Paritsis, F. Tiribelli, J. M. Morales, T. Kitzberger, J. H. Gowda, and T. T. Veblen. 2017. Effects of biological legacies and herbivory on fuels and flammability traits: a long-term experimental study of alternative stable states. Journal of Ecology 105:1309-1322. https://doi.org/10.1111/1365$\underline{-2745.12796}$

Bond, W. J., and J. J. Midgley. 2012. Fire and the angiosperm revolutions. International Journal of Plant Sciences 173:569-583. https://doi.org/10.1086/665819

Bowman, D. M. J. S., J. K. Balch, P. Artaxo, W. J. Bond, J. M. Carlson, M. A. Cochrane, C. M. D'Antonio, R. S. DeFries, J. C. Doyle, S. P. Harrison, F. H. Johnston, J. E. Keeley, M. A. Krawchuk, C. A. Kull, J. B. Marston, M. A. Moritz, I. C. Prentice, C. I. Roos, A. C. Scott, T. W. Swetnam, G. R. van der Werf, and S. J. Pyne. 2009. Fire in the Earth system. Science 324:481-484. https://doi.org/10.1126/science.1163886

Bowman, D. M. J. S., J. Balch, P. Artaxo, W. J. Bond, M. A. Cochrane, C. M. D'Antonio, R. DeFries, F. H. Johnston, J. E. 
Keeley, M. A. Krawchuk, C. A. Kull, M. Mack, M. A. Moritz, S. Pyne, C. I. Roos, A. C. Scott, N. S. Sodhi, and T. W. Swetnam. 2011. The human dimension of fire regimes on Earth. Journal of Biogeography 38:2223-2236. https://doi.org/10.1111/ j.1365-2699.2011.02595.x

Bradstock, R. A., A. M. Gill, and R. J. Williams. 2012. Flammable Australia: fire regimes, biodiversity and ecosystems in a changing world. CSIRO Publishing, Melbourne, Australia. https://doi. org/10.1071/9780643104839

Bradstock, R. A., D. A. Keith, and T. D. Auld. 1995. Fire and conservation: imperatives and constraints on managing for diversity. Pages 323-333 in R. A. Bradstock, T. D. Auld, D. A. Keith, R. T. Kingsford, D. Lunney, and D. P. Sivertsen, editors. Conserving biodiversity: threats and solutions. Surrey Beatty \& Sons, Australia.

Brooks, M. L., C. M. D'Antonio, D. M. Richardson, J. B. Grace, J. E. Keeley, J. M. DiTomaso, R. J. Hobbs, M. Pellant, and D. Pyke. 2004. Effects of invasive alien plants on fire regimes. BioScience 54:677-688. https://doi.org/10.1641/0006-3568(2004) 054[0677:EOIAPO]2.0.CO;2

Butz, R. J. 2009. Traditional fire management: historical fire regimes and land use change in pastoral East Africa. International Journal of Wildland Fire 18:442-450. https://doi.org/10.1071/ WF07067

Dass, P., B. Z. Houlton, Y. P. Wang, and D. Warlind. 2018. Grasslands may be more reliable carbon sinks than forests in California. Environmental Research Letters 13:7. https://doi. org/10.1088/1748-9326/aacb39

Dearing, J. A., A. K. Braimoh, A. Reenberg, B. L. Turner, and S. van der Leeuw. 2010. Complex land systems: the need for long time perspectives to assess their future. Ecology and Society 15 (4):21. https://doi.org/10.5751/ES-03645-150421

Eloy, L., B. A. Bilbao, J. Mistry, and I. B. Schmidt. 2019. From fire suppression to fire management: advances and resistances to changes in fire policy in the savannas of Brazil and Venezuela. Geographical Journal 185:10-22. https://doi.org/10.1111/geoj.12245

Environmental Systems Research Institute (ESRI). 2011. ArcGIS Desktop. ESRI, Redlands, California, USA.

Evangelista, P., P. Swartzinski, and R. Waltermire. 2007. A profile of the mountain nyala (Tragelaphus buxtoni). African Indaba 5 (2).

Fernandes, P. M. 2013. Fire-smart management of forest landscapes in the Mediterranean basin under global change. Landscape and Urban Planning 110:175-182. https://doi. org/10.1016/j.landurbplan.2012.10.014

Fernandes, P. M., G. M. Davies, D. Ascoli, C. Fernández, F. Moreira, E. Rigolot, C. R. Stoof, J. A. Vega, and D. Molina. 2013. Prescribed burning in southern Europe: developing fire management in a dynamic landscape. Frontiers in Ecology and the Environment 11:E4-E14. https://doi.org/10.1890/120298

Fetene, M., Y. Assefa, M. Gashaw, Z. Woldu, and E. Beck. 2006. Diversity of Afroalpine vegetation and ecology of treeline species in the Bale Mountains, Ethiopia, and the influence of fire. Pages 25-38 in E. M. Spehn, M. Liberman, and C. Korner, editors. Land use change and mountain biodiversity. CRC Press-Taylor \& Francis Group, Boca Raton, Florida, USA. https://doi.org/10.1201/9781420002874-2

Food and Agriculture Organization (FAO). 2011. Communitybased fire management: a review. FAO, Rome, Italy.

Gil-Romera, G., C. Adolf, B. M. Benito, L. Bittner, M. U. Johansson, D. A. Grady, H. F. Lamb, B. Lemma, M. Fekadu, B. Glaser, B. Mekonnen, M. Sevilla-Callejo, M. Zech, W. Zech, and G. Miehe. 2019. Long-term fire resilience of the Ericaceous Belt, Bale Mountains, Ethiopia. Biology Letters 15:20190357. https:// doi.org/10.1098/rsbl.2019.0357

Gill, A. M. 1975. Fire and the Australian flora: a review. Australian Forestry 38:4-25. https://doi.org/10.1080/00049158.1975.10675618

Gustafsson, J. 2009. Habitat and plant selection of livestock in a fire-managed Afro-alpine heathland in Ethiopia. Thesis. Swedish University of Agricultural Science, Uppsala, Sweden.

Hedberg, O. 1964. Features of Afroalpine plant ecology. Swedish Phytogeographical Society, Uppsala, Sweden.

Hemp, A. 2005. Climate change-driven forest fires marginalize the impact of ice cap wasting on Kilimanjaro. Global Change Biology 11:1013-1023. https://doi.org/10.1111/j.1365-2486.2005.00968. $\underline{\mathrm{X}}$

Hillman, J. C. 1988. The Bale Mountains National Park Area, southeast Ethiopia, and its management. Mountain Research and Development 8:253-258. https://doi.org/10.2307/3673456

Hobbs, R. J., and C. H. Gimingham. 1987. Vegetation, fire and herbivore interactions in heathland. Advances in Ecological Research 16:87-173. https://doi.org/10.1016/S0065-2504(08) 60088-4

Jacob, M., S. Annys, A. Frank1, M. De Ridder, H. Beeckman, E. Guyassa, and J. Nyssen. 2015. Tree line dynamics in the tropical African highlands - identifying drivers and dynamics. Journal of Vegetation Science 26:9-20. https://doi.org/10.1111/jvs.12215

Jira, G., A. Bekele, G. Hemson, and B. Mundanthra. 2013. Rodents in fire affected heather shrublands in Bale Mountains National Park, Ethiopia. Journal of King Saud University-Science 25:289-295. https://doi.org/10.1016/j.jksus.2013.05.006

Johansson, M., C. A. Frisk, S. Nemomissa, and K. Hylander. 2018. Disturbance from traditional fire management in subalpine heathlands increases Afro-alpine plant resilience to climate change. Global Change Biology 24:2952-2964. https://doi. org/10.1111/gcb.14121

Johansson, M. U., M. Fetene, A. Malmer, and A. Granström. 2012. Tending for cattle: traditional fire management in Ethiopian montane heathlands. Ecology and Society 17(3):19. https://doi. org/10.5751/ES-04881-170319

Johansson, M. U., and A. Granström. 2014. Fuel, fire and cattle in African highlands: traditional management maintains a mosaic heathland landscape. Journal of Applied Ecology 51:1396-1405. https://doi.org/10.1111/1365-2664.12291

Johnson, C. N., L. D. Prior, S. Archibald, H. M. Poulos, A. M. Barton, G. J. Williamson, and D. M. J. S. Bowman. 2018. Can trophic rewilding reduce the impact of fire in a more flammable 
world? Philosophical Transactions of the Royal Society B: Biological Sciences 373(1761). https://doi.org/10.1098/rstb.2017.0443

Jury, M. R. 2016. Determinants of southeast Ethiopia seasonal rainfall. Dynamics of Atmospheres and Oceans 76:63-71. https:// doi.org/10.1016/j.dynatmoce.2016.08.004

Keeley, J. E. 2002. Native American impacts on fire regimes of the California coastal ranges. Journal of Biogeography 29:303-320. https://doi.org/10.1046/j.1365-2699.2002.00676.x

Keeley, J. E., W. J. Bond, R. A. Bradstock, J. G. Pausas, and P. W. Rundel. 2012. Fire in Mediterranean ecosystems: ecology, evolution and management. Cambridge University Press, Cambridge, UK. https://doi.org/10.1017/CBO9781139033091

Keeley, J. E., and C. J. Fotheringham. 2001. History and management of crown-fire ecosystems: a summary and response. Conservation Biology 15:1561-1567. https://doi.org/10.1046/ j.1523-1739.2001.t01-1-00186.x

Keith, D. A., D. Lindenmayer, A. Lowe, J. Russel-Smith, S. Barrett, N. Enright, B. Fox, G. Guerin, D. Panton, M. Tozer, and C. Yates. 2014. Heathlands. Pages 283-334 in D. Lindenmayer, E. Burns, N. Thurgate, and A. Lowe, editors. Biodiversity and environmental change: monitoring, challenges and direction. CSIRO Publishing. https://doi.org/10.1071/9780643108578

Khatun, K., E. Corbera, and S. Ball. 2016. Fire is REDD+: offsetting carbon through early burning activities in south-eastern Tanzania. Oryx 51:43-52. https://doi.org/10.1017/S0030605316000090

Kull, C. A., and P. Laris. 2009. Fire ecology and fire politics in Mali and Madagascar. Pages 171-226 in M. A. Cochrane, editor. Tropical fire ecology: climate change, land use, and ecosystem dynamics. Springer-Verlag, Berlin, Germany. https://doi. org/10.1007/978-3-540-77381-8 7

Laris, P., and D. A. Wardell. 2006. Good, bad or 'necessary evil'? Reinterpreting the colonial burning experiments in the savanna landscapes of West Africa. Geographical Journal 172:271-290. https://doi.org/10.1111/j.1475-4959.2006.00215.x

Lovreglio, R., O. Meddour-Sahar, and V. Leone. 2014. Goat grazing as a wildfire prevention tool: a basic review. iForest Biogeosciences and Forestry 7:260-268. https://doi.org/10.3832/ ifor1112-007

Marques, D., M. Fachada, and H. Viana. 2017. Synergies between goat grazing and shrub biomass in mountain areas. Pages 155-175 in J. Simões and C. Gutiérrez, editors. Sustainable goat production in adverse environments: Volume I: welfare, health and breeding. Springer International, Cham, Switzerland. https://doi. org/10.1007/978-3-319-71855-2 10

Mekonnen, Z., H. Kassa, T. Woldeamanuel, and Z. Asfaw. 2018. Analysis of observed and perceived climate change and variability in Arsi Negele District, Ethiopia. Environment Development and Sustainability 20:1191-1212. https://doi.org/10.1007/s10668-017-9934-8

Miehe, G., and S. Miehe. 1994. Ericaceous forests and heathlands in the Bale mountains of South Ethiopia: ecology and man's impact. Stiftung Walderhaltung in Afrika, Hamburg, Germany.

Minnich, R. A., and Y. H. Chou. 1997. Wildland fire patch dynamics in the chaparral of southern California and northern
Baja California. International Journal of Wildland Fire 7:221-248. https://doi.org/10.1071/WF9970221

Mokria, M., A. Gebrekirstos, A. Abiyu, M. Van Noordwijk, and A. Bräuning. 2017. Multi-century tree-ring precipitation record reveals increasing frequency of extreme dry events in the upper Blue Nile River catchment. Global Change Biology 23:5436-5454. https://doi.org/10.1111/gcb.13809

Murphy, B. P., M. A. Cochrane, and J. Russell-Smith. 2015. Prescribed burning protects endangered tropical heathlands of the Arnhem Plateau, northern Australia. Journal of Applied Ecology 52:980-991. https://doi.org/10.1111/1365-2664.12455

Neumann, F. H., L. Scott, and M. K. Bamford. 2011. Climate change and human disturbance of fynbos vegetation during the late Holocene at Princess Vlei, Western Cape, South Africa. Holocene 21:1137-1149. https://doi.org/10.1177/0959683611400461

Neumann, R. P. 1998. Imposing wilderness: struggles over livelihood and nature preservation in Africa. University of California Press, Berkeley, California, USA.

Neumann, R. P. 2014. Stories of nature's hybridity in Europe: implications for forest conservation in the Global South. Pages 31-44 in S. B. Hecht, K. D. Morrison, and C. Padoch, editors. The social lives of forests: past, present, and future of woodland resurgence. The University of Chicago Press, Chicago, Illinois, USA. https://doi.org/10.7208/chicago/9780226024134.003.0004

Oromia Forest and Wildlife Enterprise. 2016. Bale Mountains Eco-region REDD+ project monitoring and implementation report. Oromia Forest and Wildlife Enterprise, Farm Africa, SOS Sahel, Addis Ababa, Ethiopia.

Parr, C. L., C. E. R. Lehmann, W. J. Bond, W. A. Hoffmann, and A. N. Andersen. 2014. Tropical grassy biomes: misunderstood, neglected, and under threat. Trends in Ecology \& Evolution 29:205-213. https://doi.org/10.1016/j.tree.2014.02.004

Pausas, J. G., and S. Fernández-Muñoz. 2012. Fire regime changes in the Western Mediterranean Basin: from fuel-limited to drought-driven fire regime. Climatic Change 110:215-226. https:// doi.org/10.1007/s10584-011-0060-6

Pausas, J. G., and J. E. Keeley. 2009. A burning story: the role of fire in the history of life. BioScience 59:593-601. https://doi. org/10.1525/bio.2009.59.7.10

Pausas, J. G., and J. E. Keeley. 2014. Abrupt climate-independent fire regime changes. Ecosystems 17:1109-1120. https://doi. org/10.1007/s10021-014-9773-5

Pyne, S. J. 1997. Vestal fire: an environmental history, told through fire, of Europe and Europe's encounter with the world. University of Washington Press, Seattle, Washington, USA.

Pyne, S. J. 2016. Fire in the mind: changing understandings of fire in Western civilization. Philosophical Transactions of the Royal Society B: Biological Sciences 371:8. https://doi. org/10.1098/rstb.2015.0166

R Core Team. 2014. R: A language and environment for statistical computing. R Foundation for Statistical Computing, Vienna, Austria. 
Rundel, P. W. 1998. Landscape disturbance in Mediterraneantype ecosystems: an overview. Pages 3-22 in P. W. Rundel, G. Montenegro, and F. M. Jaksic, editors. Landscape disturbance and biodiversity in Mediterranean-type ecosystems. Springer, Berlin, Germany. https://doi.org/10.1007/978-3-662-03543-6 1

Russell-Smith, J., P. G. Ryan, and D. C. Cheal. 2002. Fire regimes and the conservation of sandstone heath in monsoonal northern Australia: frequency, interval, patchiness. Biological Conservation 104:91-106. https://doi.org/10.1016/S0006-3207(01)00157-4

Sass-Klaassen, U., C. Couralet, Y. Sahle, and F. J. Sterck. 2008. Juniper from Ethiopia contains a large-scale precipitation signal. International Journal of Plant Sciences 169:1057-1065. https://doi. org/10.1086/590473

Schüler, L., A. Hemp, W. Zech, and H. Behling. 2012. Vegetation, climate and fire-dynamics in East Africa inferred from the Maundi crater pollen record from Mt Kilimanjaro during the last glacial-interglacial cycle. Quaternary Science Reviews 39:1-13. https://doi.org/10.1016/j.quascirev.2012.02.003

Seydack, A. H. W., S. J. Bekker, and A. H. Marshall. 2007. Shrubland fire regime scenarios in the Swartberg Mountain Range, South Africa: implications for fire management. International Journal of Wildland Fire 16:81-95. https://doi. org/10.1071/WF06015

Strömberg, C. A. E. 2011. Evolution of grasses and grassland ecosystems. Annual Review of Earth and Planetary Sciences 39:517-544. https://doi.org/10.1146/annurev-earth-040809-152402

Syphard, A. D., T. J. Brennan, and J. E. Keeley. 2019. Drivers of chaparral type conversion to herbaceous vegetation in coastal Southern California. Diversity and Distributions 25:90-101. https://doi.org/10.1111/ddi.12827

Teketay, D. 2000. Vegetation types and forest fire management in Ethiopia. Pages 1-35 in Proceedings: Round Table Conference on Integrated Forest Fire Management in Ethiopia, Addis Ababa, Ethiopia.

Tesfaye, Y., A. Roos, B. J. Campbell, and F. Bohlin. 2012. Factors associated with the performance of user groups in a participatory forest management around Dodola Forest in the Bale Mountains, southern Ethiopia. Journal of Development Studies 48:1665-1682. https://doi.org/10.1080/00220388.2012.714123

Umer, M., H. F. Lamb, R. Bonnefille, A.-M. Lézine, J.-J. Tiercelin, E. Gibert, J.-P. Cazet, and J. Watrin. 2007. Late Pleistocene and Holocene vegetation history of the Bale Mountains, Ethiopia. Quaternary Science Reviews 26:2229-2246. https://doi.org/10.1016/ j.quascirev.2007.05.004

van Breugel, P., I. Friis, S. Demissew, J.-P. B. Lillesø, and R. Kindt. 2016. Current and future fire regimes and their influence on natural vegetation in Ethiopia. Ecosystems 19:369-386. https:// doi.org/10.1007/s10021-015-9938-X

van Wilgen, B. W. 2013. Fire management in species-rich Cape fynbos shrublands. Frontiers in Ecology and the Environment 11: e35-e44. https://doi.org/10.1890/120137

Vial, F., D. W. Macdonald, and D. T. Haydon. 2011. Limits to exploitation: dynamic food web models predict the impact of livestock grazing on Ethiopian wolves Canis simensis and their prey. Journal of Applied Ecology 48:340-347. https://doi. org/10.1111/j.1365-2664.2010.01943.x

Watson, C., S. Mourato, and E. J. Milner-Gulland. 2013. Uncertain emission reductions from forest conservation: REDD in the Bale Mountains, Ethiopia. Ecology and Society 18(3):6. https://doi.org/10.5751/ES-05670-180306

Wesche, K. 2006. Is Afroalpine plant biodiversity negatively affected by high-altitude fires? Pages 39-50 in E. M. Spehn, M. Liberman, and C. Korner, editors. Land use change and mountain biodiversity. CRC Press, Taylor \& Francis Group, Boca Raton, Florida, USA. https://doi.org/10.1201/9781420002874-3

Wesche, K., G. Miehe, and M. Kaeppeli. 2000. The significance of fire for Afroalpine Ericaceous vegetation. Mountain Research and Development 20:340-347. https://doi.org/10.1659/0276-4741 (2000)020[0340:TSOFFA]2.0.CO;2

Williams, J. 2013. Exploring the onset of high-impact mega-fires through a forest land management prism. Forest Ecology and Management 294:4-10. https://doi.org/10.1016/j.foreco.2012.06.030

Williams, R. J., C. H. Wahren, R. A. Bradstock, and W. J. Muller. 2006. Does alpine grazing reduce blazing? A landscape test of a widely-held hypothesis. Austral Ecology 31:925-936. https://doi. org/10.1111/j.1442-9993.2006.01655.X

Yibarbuk, D., P. J. Whitehead, J. Russell-Smith, D. Jackson, C. Godjuwa, A. Fisher, P. Cooke, D. Choquenot, and D. M. J. S. Bowman. 2001. Fire ecology and Aboriginal land management in central Arnhem Land, northern Australia: a tradition of ecosystem management. Journal of Biogeography 28:325-343. https://doi.org/10.1046/j.1365-2699.2001.00555.x

Zeleke, T. T., F. Giorgi, G. T. Diro, and B. F. Zaitchik. 2017. Trend and periodicity of drought over Ethiopia. International Journal of Climatology 37:4733-4748. https://doi.org/10.1002/joc.5122 
Appendix 1 - background, supporting parts of methods and results to: Change in heathland fire sizes inside vs. outside the Bale Mountains National Park, Ethiopia, over 50 years of fire-exclusion policy: Lessons for REDD

\section{METHODS Study Area - geology, climate, vegetation, land use history}

The Bale Mountains bedrock originates from Tertiary basaltic lava and soils are dark-brown silty loams, rich in organic matter (Yimer, Ledin \& Abdelkadir 2006). The Sanetti Plateau >4000 m.a.s.l. was during the last glacial maximum covered by an ice cap, which disappeared at least 2000 years ago (Osmaston et al. 2005, Umer et al. 2007). The climate is tropical alpine with large diurnal fluctuations in temperature; average max/min temperatures at $3400 \mathrm{~m}$ on the Northern aspect are $\sim 15$ and $5{ }^{\circ} \mathrm{C}$ (Johansson and Granström 2014), with larger fluctuations, and night frosts in the dry season (Miehe and Miehe 1994). The dry season normally lasts from December-January, but some rain falls also in the dry season. The dry season on northern aspect is slightly longer, with a mean annual precipitation at $3400 \mathrm{~m}$.a.s.l. of $\sim 1740 \mathrm{~mm}$ (Johansson and Granström 2014). On the southern aspect total precipitation is lower, but more evenly distributed throughout the year, with persistent fogs at the treeline (Miehe and Miehe 1994). Some years the dry season extends into March-April due to failure of the south-eastern monsoon (the short "Belg" rains), causing regional extended droughts (Miehe and Miehe 1994, Mokria et al. 2017, Mekonnen et al. 2018) (Table A1.1).

The montane vegetation forms distinct zones with sharp boundaries (Friis 1986). These zones should have been upward migrating during the last 4000-year general warming trend in Africa (Kebede et al. 2007, Chala et al. 2016), but the distinct treeline (at 3500 m.a.s.1.) has probably been rather stable (Gil-Romera et al. 2019), due to the contrasting flammability between the highly flammable heathlands above, and the less flammable forests below (Johansson 2013, Johansson and Granström 2014). Increased anthropogenic ignition probably dates back more than 2000 years (Mohammed and Bonnefille 1998, Umer et al. 2007, Gil-Romera et al. 2019). Below 3500 m.a.s.l. Erica trimera forms a 8-12 m tall cloud-forest belt (Friis 1986, Wesche et al. 2008). This closed-canopy forest rarely burns due to lack of surface fuels and a moist interior climate (Johansson 2013). Between 3500-3900 m.a.sl. shrub-shaped, lignotuberous Erica trimera and Erica arborea form an almost continuous heathland vegetation belt, interrupted only by small streams, mires and small rocky outcrops (Miehe and Miehe 1994, Fetene et al. 2006). Above 3900 m.a.sl., the Afroalpine zone is dominated by alpine tussock grasslands and sparse Helichrysum dwarf shrub with isolated stunted Erica trimera stands in sheltered sites (Friis 1986, Miehe and Miehe 1994).

Until recently the indigenous Bale Oromo inhabitants practised a pure cattle-based transhumant pastoralism, mainly utilizing the heathlands in the dry season. Early $20^{\text {th }}$-century travel records (Erlanger 1904, Mooney 1963) describe a burnt and grazed ericaceous heathland, quite similar to the present state. The Rinderpest epizootic in the late 1890's severely decimated livestock and human populations in Bale (Pankhurst 1966). Since the 1950's population density has rapidly increased (Hillman 1988, Tesfaye et al. 2012). Due to night-time frosts livestock still provide the major source of income at high altitudes. Permanent homesteads are traditionally located below the tree line, and cows, bulls and horses are herded daily up to the heathlands to range freely.

Table A1.1. Extended drought years in the Bale Mountains.

\begin{tabular}{l|l}
\hline Fire-year & Comment \\
\hline $1973 / 1974$ & Regional drought, short rains failure, large areas burnt, including Erica forest \\
$1983 / 1984$ & Regional drought, short rains failure \\
$1999 / 2000$ & Short rains failure, large areas burnt, including Erica forest \\
$2007 / 2008$ & Short rains failure, burning until April, large areas burnt, including Erica forest \\
$2011 / 2012$ & Short rains failure, burning until April \\
$2014 / 2015$ & Short rains failure, burning until April, one person died \\
\hline
\end{tabular}

Sources: Jury 2016, Sass-Klaassen et al. 2008, Mokria et al. 2017, Zeleke et al. 2017, Jury 2016, Belayneh et al. 2013, Abera and Kinahan 2011, and personal observations 2005-2016. 


\section{METHODS Remote-sensed imagery acquisition and handling}

Aerial photos were bought from the Ethiopian Mapping Authority (EMA). Satellite images were provided by USGS and ESA. Images were resampled, mosaicked, aligned and re-projected to coordinate system UTM zone 37N (WGS84). Image resolution differed between years, but in order not to bias our random sample selection that is carried out using a standard $500 \mathrm{~m}$ grid system (Figure 3) across all years, we pansharpened $30 \mathrm{~m}$ images to $15 \mathrm{~m}$, and then resampled them to $20 \mathrm{~m}$ to give most images a resolution of $20 \mathrm{~m}$. No distortions were introduced due to resampling. Exception was made for the 1973 image $(60 \mathrm{~m})$ due to lack of high resolution data in the 70's, as well as for the aerial imagery from 1968 and 1984 due to difficulties in interpreting $\mathrm{B} \& \mathrm{~W}$ imagery. To compare delineation accuracy between high-resolution panchromatic aerial photos, and the $20 \mathrm{~m}$ resolution satellite images, we used the delineated stand borders from the 1984 aerial photos and superimposed them on the 1987 satellite image, and stand borders largely matched (+/- $10 \mathrm{~m})$. We resampled the pansharpened Landsat images to $20 \mathrm{~m}$ to keep as many of the images as possible within the same spatial resolution so the random sampling analysis is not biased. Keeping the spatial unit was necessary since the same standard grid was used to randomly select points that identify patches that were further analysed throughout the research timeframe.

Table A1.2. Used imagery information summary (note, 1999 and 2015 were not used in the time-series)

\begin{tabular}{|c|c|c|c|c|c|c|c|}
\hline $\begin{array}{l}\text { Jan. } \\
\text { Year }\end{array}$ & Sensor & Resolution & $\begin{array}{l}\text { Bands } \\
\text { used }\end{array}$ & Tiles & Image Dates & Source & ID \\
\hline 1968 & $\begin{array}{l}\text { Aerial } \\
\text { photos }\end{array}$ & $2-5 m$ & $B \& W$ & 26 & $\begin{array}{l}\text { Nov 30, Dec5 } \\
1967\end{array}$ & EMA & \\
\hline 1973 & $\begin{array}{l}\text { Landsat } \\
\text { MSS }\end{array}$ & $60 m$ & $\begin{array}{l}\text { Green, } \\
\text { Red, NIR }\end{array}$ & 1 & $\begin{array}{l}\operatorname{Jan} 30 \\
1973\end{array}$ & USGS/EROS & LM11800551973030AAA04 \\
\hline 1984 & $\begin{array}{l}\text { Aerial } \\
\text { photos }\end{array}$ & $2-5 m$ & $B \& W$ & 26 & $\begin{array}{l}\text { January } 17 \\
1984\end{array}$ & EMA & \\
\hline 1987 & SPOT1 & $10 / 20 m$ & $\begin{array}{l}\text { B\&W/ } \\
\text { Green, } \\
\text { Red, NIR }\end{array}$ & 4 & $\begin{array}{l}\text { Dec 15, } 311986 \\
\text { Jan 30, } 1987\end{array}$ & $\begin{array}{l}\text { SPOT1-5 } \\
\text { ESA archive }\end{array}$ & $\begin{array}{l}11403368612310745582 \mathrm{P} \\
11403378612310746062 \mathrm{P} \\
11403368701300808522 \mathrm{P} \\
11413368612150753481 \mathrm{X}\end{array}$ \\
\hline 1995 & SPOT3 & $20 m$ & $\begin{array}{l}\text { Green, } \\
\text { Red, NIR }\end{array}$ & 2 & Jan 16, 1995 & $\begin{array}{l}\text { SPOT1-5 } \\
\text { ESA archive }\end{array}$ & $\begin{array}{l}31403369501160752162 X \\
31403379501160752242 X\end{array}$ \\
\hline 1999 & SPOT4 & $20 m$ & $\begin{array}{l}\text { Green, } \\
\text { Red, NIR }\end{array}$ & 3 & $\begin{array}{l}\text { Jan 02, } 28 \\
1999\end{array}$ & $\begin{array}{l}\text { SPOT1-5 } \\
\text { ESA archive }\end{array}$ & $\begin{array}{l}414033699010207425621 \\
414133699012807424711 \\
41413379901280742551 I\end{array}$ \\
\hline 2000 & $\begin{array}{l}\text { Landsat } \\
7 \text { ETM+ }\end{array}$ & $\begin{array}{l}30 \mathrm{~m} \text {, pansh. } \\
\text { to } 15 \mathrm{~m}^{*}\end{array}$ & $\begin{array}{l}\text { Green, } \\
\text { Red, NIR }\end{array}$ & 2 & Feb 05, 142000 & USGS/EROS & $\begin{array}{l}\text { LE71680552000036EDC00, } \\
\text { LE71670552000045EDC00 }\end{array}$ \\
\hline 2006 & SPOT4 & $20 \mathrm{~m}$ & $\begin{array}{l}\text { Green, } \\
\text { Red, NIR }\end{array}$ & 4 & $\begin{array}{l}\text { Dec } 42005 \\
\text { Jan } 12006\end{array}$ & $\begin{array}{l}\text { SPOT1-5 } \\
\text { ESA archive }\end{array}$ & $\begin{array}{l}21403370601040758152 X \\
21403360601040758062 X \\
21413370512040754112 X \\
21413360512040754022 x\end{array}$ \\
\hline 2008 & SPOT4 & $20 m$ & $\begin{array}{l}\text { Green, } \\
\text { Red, NIR }\end{array}$ & 4 & Feb 11, 122008 & $\begin{array}{l}\text { SPOT1-5 } \\
\text { ESA archive }\end{array}$ & $\begin{array}{l}41403370802120738422 I \\
414133708021107580021 \\
414133608021107575221 \\
414033608021207383421\end{array}$ \\
\hline 2011 & SPOT4 & $20 m$ & $\begin{array}{l}\text { Green, } \\
\text { Red, NIR }\end{array}$ & 5 & $\begin{array}{l}\text { Nov } 192010- \\
\text { Jan } 252011\end{array}$ & $\begin{array}{l}\text { SPOT1-5 } \\
\text { ESA archive }\end{array}$ & $\begin{array}{l}41423371011190718141 \mid \\
41393361012190740191 I \\
41413361101100716151 I \\
41403361101250727112 I \\
41403371101250727192 I\end{array}$ \\
\hline 2015 & $\begin{array}{l}\text { Landsat } \\
8 \mathrm{OLI}\end{array}$ & $\begin{array}{l}30 \mathrm{~m} \text {, pansh. } \\
\text { to } 15 \mathrm{~m}^{*}\end{array}$ & 11 bands & 2 & $\begin{array}{l}\operatorname{Jan} 5,14 \\
2015\end{array}$ & USGS/EROS & $\begin{array}{l}\text { LC81680552015005LGN01 } \\
\text { LC81670562015014LGN01 }\end{array}$ \\
\hline 2017 & $\begin{array}{l}\text { Landsat } \\
8 \text { OLI }\end{array}$ & $\begin{array}{l}30 \mathrm{~m} \text {, pansh. } \\
\text { to } 15 \mathrm{~m}^{*}\end{array}$ & 11 bands & 2 & $\begin{array}{l}\operatorname{Jan} 3,10 \\
2017\end{array}$ & USGS/EROS & $\begin{array}{l}\text { LC81670552017003LGN01, } \\
\text { LC81680552017010LGN01 }\end{array}$ \\
\hline
\end{tabular}

Jan. Year=the January year of the (Nov-April) dry season, MSS=mobile satellite services, OLI=operational land imager, $\mathrm{B} \& \mathrm{~W}=$ =black-and white, NIR=near infrared, EMA=Ethiopian mapping authority, USGS=US geological services, EROS=Earth resources observation and sciences. *30 m images pansharpened to $15 \mathrm{~m}$, then resampled to $20 \mathrm{~m}$. 


\section{METHODS Remote-sensed imagery, continued:}

Aerial photos were georeferenced using ArcMap 10.6, using GCP's taken from Google Earth of stable features in the landscape such as roads, streams, boulders and other landforms. A minimum of 8 points were used for each image to reach a total root mean square error (RMSE) of less than $5 \mathrm{~m}$ when possible, and an optical check was done for each image to check its local accuracy in the heathland zone against a backdrop of satellite images. Sample points for patch size quantification were selected using a $500 \mathrm{~m}$ grid system, with 556 and 791 gridpoints outside/inside the park respectively (Figure 3). We used the Sampling Design Tool for ArcGIS (2007) to randomly select new sample points from the grid for each analysed year (i.e. no replication in time). For each year we selected 54 random points outside and 54 points inside the Bale Mountains National Park (BMNP) (representing 9.7\% and $6.8 \%$ of all gridpoints), since we did not want to have fewer sampling points in the smaller area outside the park. When two random points landed on the same patch (occurred 14 times), the second point was ignored for the main analyses. In the first analysis of proportion of points on burnt/young stands, duplicates were included.

\section{Ground truthing}

In June 2018 four 2-4 km long line transects (total $14.6 \mathrm{~km}$ ) inside the park were mapped by gps using the same methods as previously for outside the park. A gps point was recorded when crossing a border between two stands of different age. Dominant heights of E. arborea and E.trimera were recoded, with stand age (based on our established age-height relations and park scout's memory of burn year). We recorded slope, aspect, area cover of grass/herb lawn, total Erica cover and \% cover of E. arborea and E.trimera. In these transects the oldest stand was $\sim 25$ years old and one stand was $<1$ year old. The proportion of young stands ( $<4$ years) was $26 \%$. The transect data was verified against Google Earth CNES/Airbus images from February 2018. Borders between young and mature stands fitted with Google Earth images (max error +/- 20 $\mathrm{m}$ ), but borders between two mature stands of different age were less clearly distinguishable. This implies that mature stands in our main analyses can be composed of two stands originating from different fire years, and hence mature stands were excluded from all statistical analyses. As ground truthing data for the area outside the park we used our previously collected data from 2007/2008 and 2016, validated against historical Google Earth images from the same years.

\section{Test of Flammability threshold age}

Thirty-four of the delineated burnt patches were investigated for their age at the time of the fire, by analysing three image pairs less than 3 year apart in time: 1999/2000, 2006/2008, 2015-2017. Pre-fire age-class of each stand was estimated by checking the age-class of the same stand in the 1-2 year predated image. Results showed that 33 of the fires burnt in mature ( $>5$ year old) stands, and only one fire occurred in a stand which was classified as young (1-3 year old) in 1984, which means that it was between 4-6 years old when it burned in 1987. No young stands burned. This confirmed our hypothesis that stands $<5$ years old cannot burn, and therefore act as fuel-breaks in the landscape. P-value from $\mathrm{Chi}^{2}$ test $=\left(\chi^{2}=13.534, \mathrm{DF}=1, \mathrm{p}=0.00023\right)$.

Table A1.3 Numbers of burnt and non-burnt stand per age class.

\begin{tabular}{lrrr}
\hline & $1999-2000$ & $2006-2008$ & $2015-2017$ \\
\hline Burnt Mature & 9 & 15 & 1 \\
Burnt Young & 0 & 0 & 0 \\
Nonburnt Mature & 32 & 25 & 36 \\
Nonburnt Young & 22 & 15 & 25 \\
\hline
\end{tabular}

Pooled > $\mathrm{x}<-$ matrix $(\mathrm{c}(25,0,93,62), \mathrm{n}$ col $=2)>\chi 2$ Pearson's

Chi-squared test with Yates' continuity correction data 


\section{RESULTS}
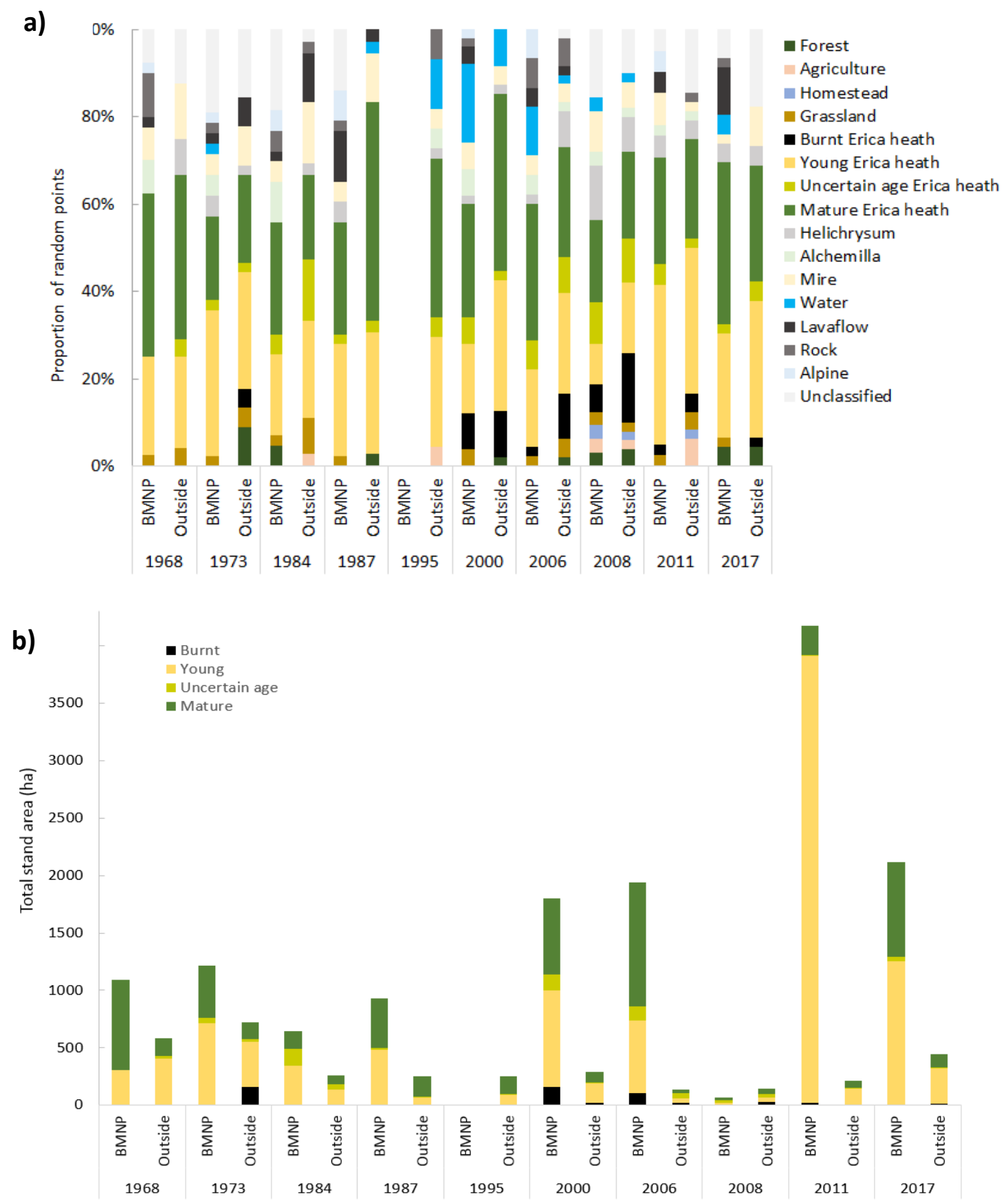

Figure A1.1 a) Proportion of sample points which fell on all identified types of land covers in the studied zone between 3500-3900 m.a.sl. b) Summed area cover for all delineated heathland patches each year for burnt, young and mature stands, and stands with uncertain age (intermediate colour, likely 4-year old stands or flat land with sparse lignotubers).

Table A1.4 Number of homesteads located within $500 \mathrm{~m}$ from delineated Erica stands inside and outside Bale Mountains National Park (BMNP).

\begin{tabular}{lll}
\hline Number of homesteads & 1968 & 2017 \\
\hline BMNP above treeline & 0 & 5 \\
BMNP below treeline & 0 & 0 \\
Outside above treeline & 2 & 11 \\
Outside below treeline & 0 & 1 \\
\hline
\end{tabular}



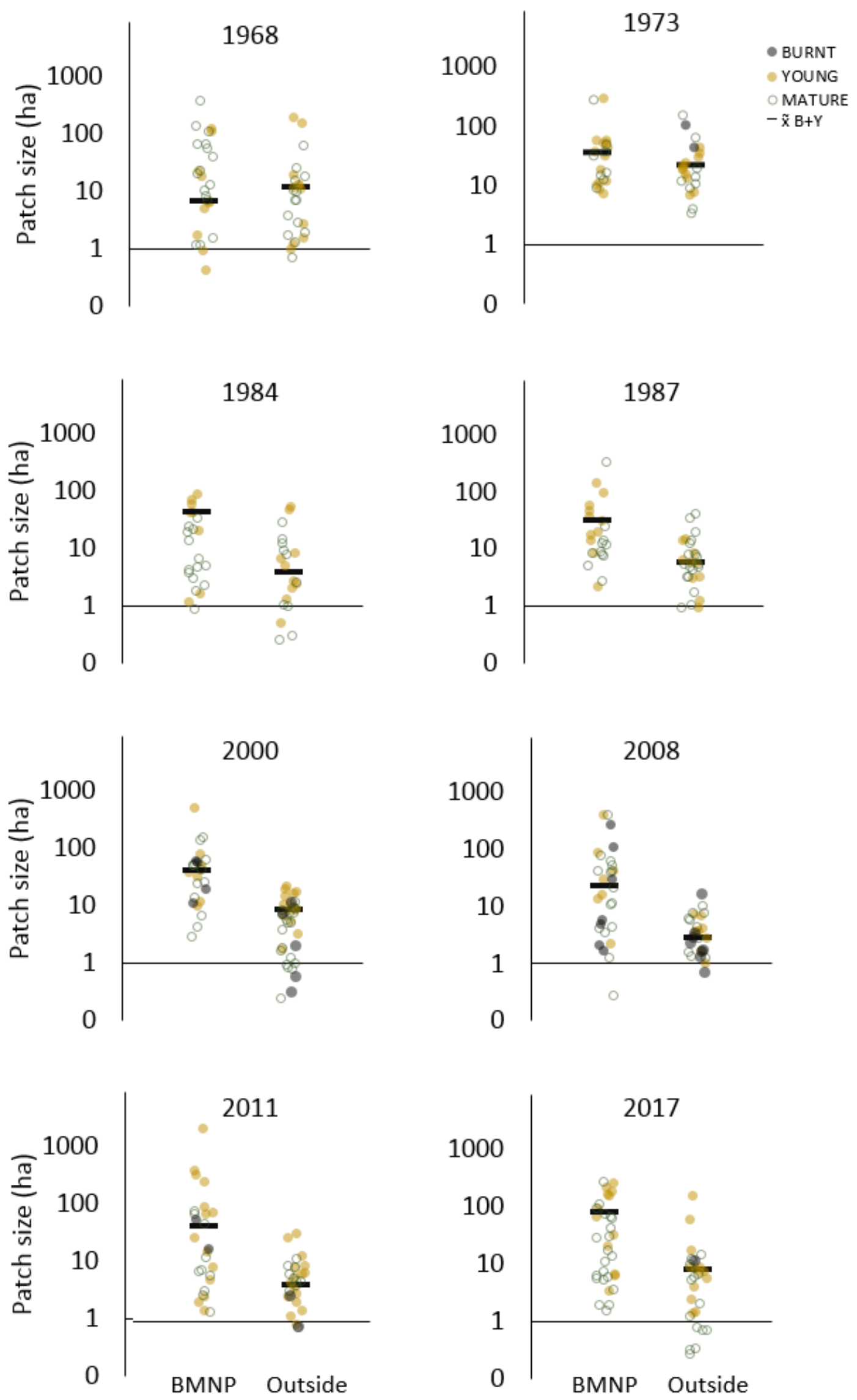

Figure A1.2. Patch sizes of burnt (grey dots), young (yellow dots) and mature stands (green circles), and the median of burnt + young stands (black line) (for 8 selected years) 1968 -2017. Inside Bale Mountains National Park (BMNP) and outside. Mature stands show similar size distributions as young stands 


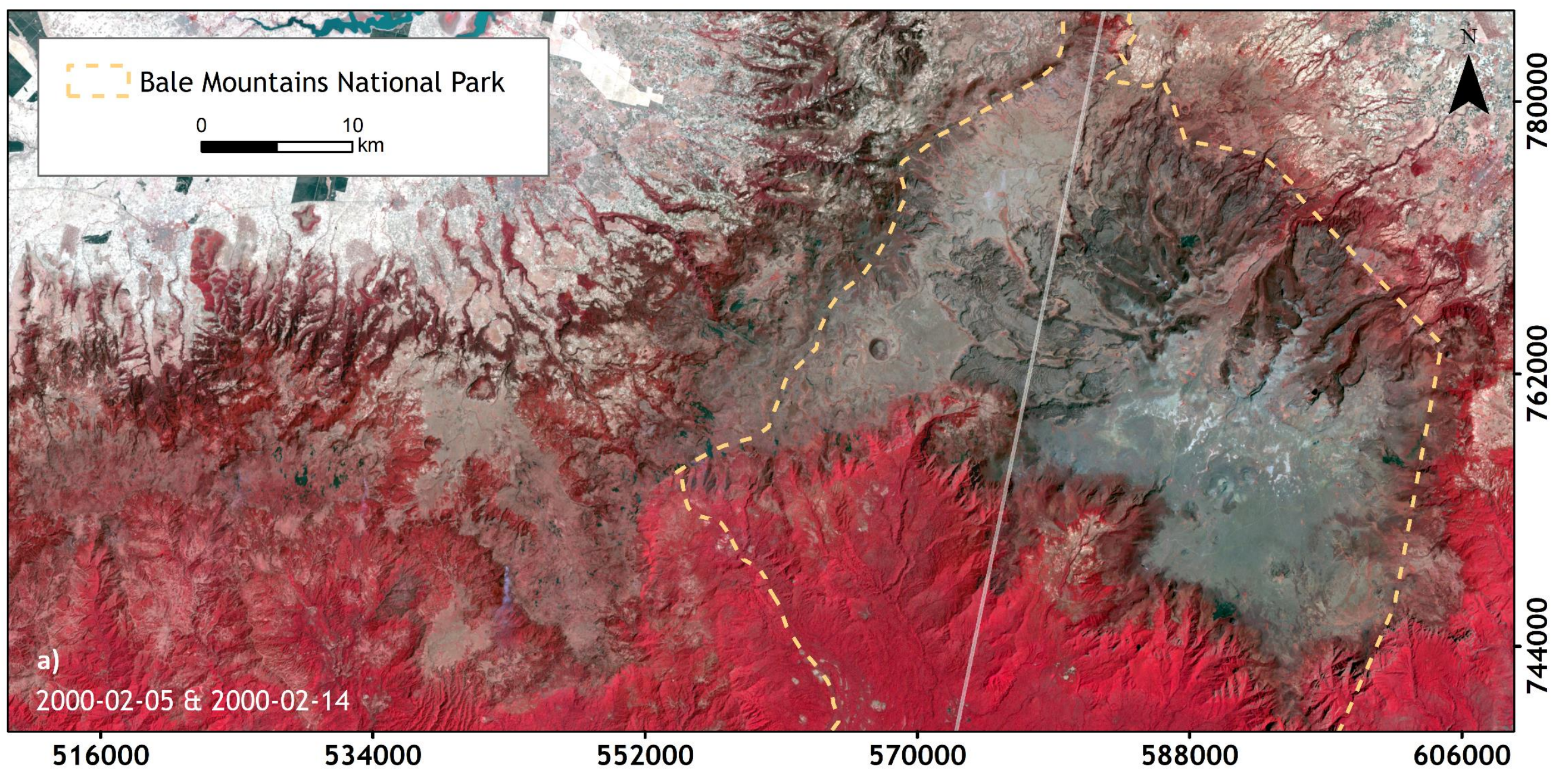

Figure A1.3 a) Bale Mountains image from drought year 1999/2000. Two tiled Landsat images from $5^{\text {th }}$ (left) and $14^{\text {th }}$ (right) from February 2000, with the BMNP border superimposed. The heathland zone appears grey-red (a patchwork of grass-dominated stands and Erica-dominated stands). A blue smoke from an active heathland fire is visible $\sim 10 \mathrm{~km}$ west of the western park border, in the lower half of the image. Black patches are stands which had burnt during the first half of the dry season 1999/2000, not including late-season fires in March-April. Large black burns are visible on the western ridge outside the park, just along the western park border, and inside the park, on the eastern slope, $\sim 10 \mathrm{~km}$ SE of Rira and along the Harenna escarpment, one large black patch can be seen in the complex lava-flow terrain north of Sanetti plateau. Many, mostly small, burnt patches are visible outside the park. 


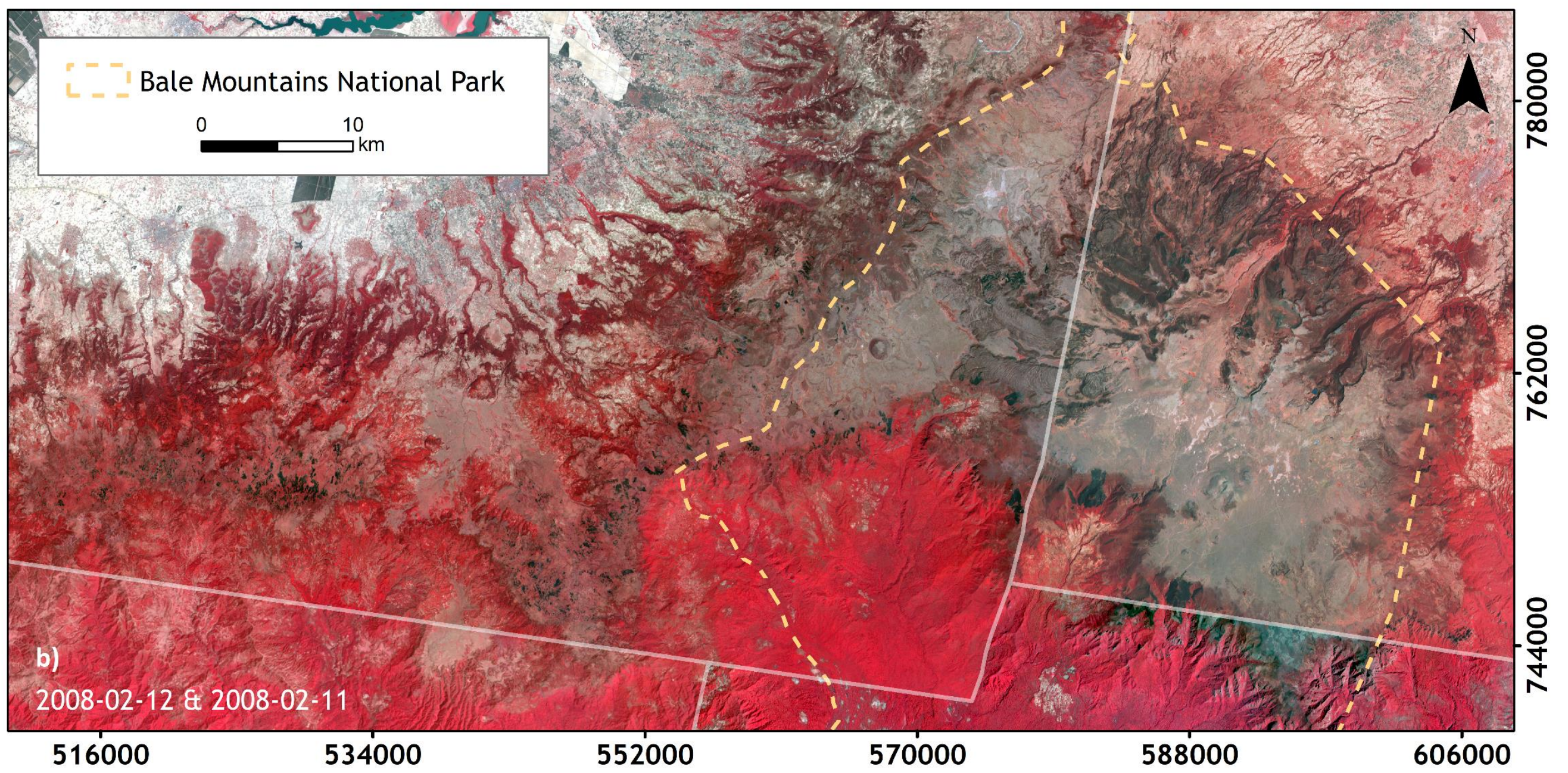

Figure A1.3 b) Bale Mountains image from drought year 2007/2008; two tiled SPOT images from 11 ${ }^{\text {th }}$ (left) and $12^{\text {th }}$ (right) of February 2008. Large ( 30-290 ha) black burns are visible along the Harenna escarpment in the park. Many small burnt patches are visible outside the park. 
Appendix 1 - background, supporting parts of methods and results to: Change in heathland fire sizes inside vs. outside the Bale Mountains National Park, Ethiopia, over 50 years of fire-exclusion policy: Lessons for REDD

Table A1.5 Livelihood parameters (average(range)) for respondents divided per wealth group, age group (young: 20-30, mid-age: 31-49, old: >50 years old), residency inside vs. outside BMNP, and on the northern vs. southern aspects of the mountain, respectively. Responses to questions were entered into a spreadsheet with demographic and livelihood data and patterns in replies were sought based on these groupings.

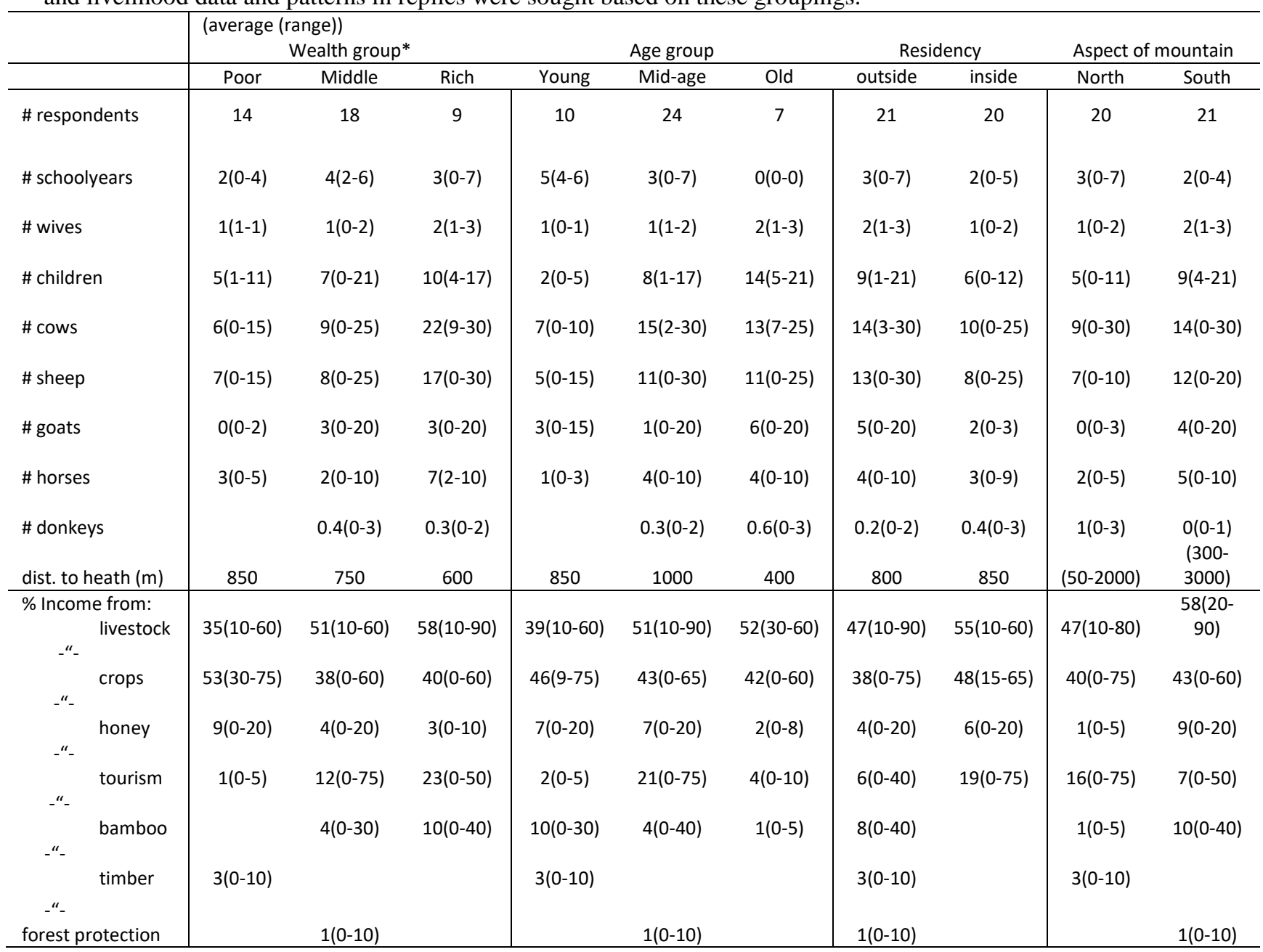

*Wealth groups based mainly on numbers of livestock and horses (for old respondents: also number of wives/homesteads, numbers of children, and social status during Imperial time (Tesfaye et al. 2012).) Respondents not separated per gender since it is summed household estimations 
Appendix 1 - background, supporting parts of methods and results to: Change in heathland fire sizes inside vs. outside the Bale Mountains National Park, Ethiopia, over 50 years of fire-exclusion policy: Lessons for REDD

\section{CITED LITERATURE}

Chala, D., C. Brochmann, A. Psomas, D. Ehrich, A. Gizaw, C. A. Masao, V. Bakkestuen, and N. E. Zimmermann. 2016. Good-bye to tropical alpine plant giants under warmer climates? Loss of range and genetic diversity in Lobelia rhynchopetalum. Ecology and Evolution 6:8931-8941.

Erlanger, C. 1904. Bericht über meine Expedition in Nordost-Afrika in den Jahren 1899-1901. Zeitschrift Der Gesellschaft Für Erdkunde Zu, Berlin.

Fetene, M., Y. Assefa, M. Gashaw, Z. Woldu, and E. Beck. 2006. Diversity of afroalpine vegetation and ecology of treeline species in the Bale Mountains, Ethiopia, and the influence of fire. Pages 25-38 in E. M. Spehn, M. Liberman, and C. Korner, editors. Land Use Change and Mountain Biodiversity. Crc Press-Taylor \& Francis Group, Boca Raton.

Friis, I. 1986. Zonation of Forest Vegetation on the South Slope of Bale Mountains, South Ethiopia. Sinet- an Ethiopian Journal of Science:29-44.

Gil-Romera, G., C. Adolf, M. Benito Blas, L. Bittner, U. Johansson Maria, A. Grady David, F. Lamb Henry, B. Lemma, M. Fekadu, B. Glaser, B. Mekonnen, M. Sevilla-Callejo, M. Zech, W. Zech, and G. Miehe. 2019. Long-term fire resilience of the Ericaceous Belt, Bale Mountains, Ethiopia. Biology Letters 15:20190357.

Hillman, J. C. 1988. The Bale Mountains National Park Area, Southeast Ethiopia, and its management. Mountain Research and Development 8:253-258.

Johansson, M. U. 2013. Fire and grazing in subalpine heathlands and forests of Bale Mountains, Ethiopia. Fire ecology and traditional use of fire. PhD Diss. Acta Universitatis agriculturae Sueciae. 2013:14.

Johansson, M. U., and A. Granström. 2014. Fuel, fire and cattle in African highlands: traditional management maintains a mosaic heathland landscape. Journal of Applied Ecology 51:1396-1405.

Kebede, M., D. Ehrich, P. Taberlet, S. Nemomissa, and C. Brochmann. 2007. Phylogeography and conservation genetics of a giant lobelia (Lobelia giberroa) in Ethiopian and Tropical East African mountains. Molecular Ecology 16:1233-1243.

Mekonnen, Z., H. Kassa, T. Woldeamanuel, and Z. Asfaw. 2018. Analysis of observed and perceived climate change and variability in Arsi Negele District, Ethiopia. Environment Development and Sustainability 20:1191-1212.

Miehe, G., and S. Miehe. 1994. Ericaceous forests and heathlands in the Bale mountains of South Ethiopia: ecology and man's impact. Stiftung Walderhaltung in Africa, Hamburg.

Mohammed, M. U., and R. Bonnefille. 1998. A late Glacial late Holocene pollen record from a highland peat at Tamsaa, Bale Mountains, south Ethiopia. Global and Planetary Change 17:121-129.

Mokria, M., A. Gebrekirstos, A. Abiyu, M. Van Noordwijk, and A. Bräuning. 2017. Multi-century tree-ring precipitation record reveals increasing frequency of extreme dry events in the upper Blue Nile River catchment. Global Change Biology:n/a-n/a.

Mooney, H. 1963. An account of twojourneys to the Araenna Mountains in Bale province (South-East Ethiopia), 1958 and 1959-60. Proceedings of the Linnean Society of London 174:127-152.

NCCOS. 2007. Sampling Design Tool for ArcGIS. National Oceanic and Atmospheric Administration, USA.

Osmaston, H. A., W. A. Mitchell, and J. A. N. Osmaston. 2005. Quaternary glaciation of the Bale Mountains, Ethiopia. Journal of Quaternary Science 20:593-606.

Pankhurst, R. 1966. The Great Ethiopian Famine of 1888-1892: A New Assessment. Journal of the History of Medicine and Allied Sciences XXI:271-294.

Tesfaye, Y., A. Roos, B. J. Campbell, and F. Bohlin. 2012. Factors Associated with the Performance of User Groups in a Participatory Forest Management around Dodola Forest in the Bale Mountains, Southern Ethiopia. The Journal of Development Studies 48:1665-1682.

Umer, M., H. F. Lamb, R. Bonnefille, A. M. Lezine, J. J. Tiercelin, E. Gibert, J. P. Cazet, and J. Watrin. 2007. Late Pleistocene and Holocene vegetation history of the Bale Mountains, Ethiopia. Quaternary Science Reviews 26:2229-2246.

Wesche, K., A. Cierjacks, Y. Assefa, S. Wagner, M. Fetene, and I. Hensen. 2008. Recruitment of trees at tropical alpine treelines: Erica in Africa versus Polylepis in South America. Plant Ecology \& Diversity 1:35-46. 


\title{
INTERVIEW QUESTIONS \& PHOTOS
}

\begin{abstract}
A. Name? B. Age? C. How long did you live here? (Why moved?) D. Education? E. How many children? F. How many cows? horses? sheep? goats? G. In which veg. zone do you 1) live? 2) graze your cattle? sheep? goats? H. proportion of income from cows? bulls? sheep? goats? horses? agriculture? forest products? other? I. How did this area look like when you were a child compared to now? J. What is the largest differences in your life between today and when you were a child? K. Is there a difference in landuse/land cover - past to present? What? Why? $\mathbf{L}$. How has the number of families/number of children per family changed over time? $\mathbf{M}$. What is the relation between people and forest - over time, in how it is used and protected? N. How has the proportional area cover of grass-trees/grass-herbs changed over time? $\mathbf{O}$. How can pasture be improved? P. What are the reasons for burning? Please rank them. Q. Fire management technique? How? Has it changed over time? How? Why?
\end{abstract}

\section{Photo question: $\quad$ Follow-up question (depending on answer):}

(Number 1-6 are lower zone forest-related questions and will be presented elsewhere)

7. What is this? (Erica forest) Economic value? Good pasture? Why? How old are the trees? Have you seen fire in this kind of forest? Can it burn? Under which conditions?

8. What is this? (Erica fence) Why do people fence grazing land? Since when did this start? Why? Good? Legal? Sustainable? What is needed to protect this forest?

9. What is this? (heathland 1 year) Value? Good pasture? Why? How old is it? Can it burn? Could young stands burn long time ago?

10. What is this? (heathland 5 yr) Good pasture? Why? How old? Which is the youngest age when it is possible to burn? Under which conditions can it burn? Is it legal to burn heath? Why?

11. What is this? (Erica old) Good pasture? Why? How old? How to improve pasture? With how many years interval should the erica burn to get best grazing? Have fire intervals decreased lately? Why? What should be done to improve heathland management?

12. What is this? (overgrazed heathland) good pasture? Why? Can Erica die by overgrazing? Good or bad? Which animals overgraze Erica? What should be done about this? Are there more cattle, or other livestock, here now than 10, 30 years ago? How many cattle per hectare (show 1 ha) can be sustainably grazed in the heathland without degrading pasture?

13. What is this? (burnt lignotuber) What happens when soil burns? When is there risk of soil fire? Was this common earlier? Can Erica die by soil fire? Good or bad? How avoid killing Erica?

14. What is this? (fuel break) What would happen if people stopped igniting in the heathland? This is the same land 2 years apart, the lower area burnt 2 years after the upper area, and the fire stopped at the then 2 year old vegetation. Why? If people did not burn, would there be any fuel breaks in the landscape? Would there be more large fires then? Or would the Erica grow into tall forest? How many years to become forest? Did you hear about the big Mount Kaka fire in 2012? Why did it burn so large area? Could this happen in Bale? Why?

15. What is this? (people trying to stop fire) Why? Is this dangerous? How can burning be planned and executed so that it is not dangerous? Did you hear of someone killed by Erica fire? Why?

16. What is this? (Big fire on Sanetti 2008) Is it good or bad fire? Is it dangerous? What does the colour of the smoke tell you? Can heathland fire ignite forest below? Why?

If the REDD+ projects plans to introduce Joint Forest and Pasture Management, what are your recommendations for how the rules should best be designed for sustainable use of the forests and the heathlands?

17. What is this? ("bokata") where is it found? E. arborealE. trimera? stand age? when? adult when? How does the adult look like? Is it a butterfly? Where does it pupate?

R. Relations between government and people? park/agr. bureau/REDD+ and people? Change over time? How should they best work with the people? S. What is REDD+? What is carbon storage? When did REDD+ start? Did you experience any changed rules since the REDD+ started? How do these rules affect your livelihood? How much carbon money do you expect for saving trees? per tree?, per ha? Will this compensate for potential loss of pasture? Did we forget to ask any question which is important for your livelihood here?

Galatoma! 
Appendix 2 - Interview questions to: Change in heathland fire sizes inside vs. outside the Bale Mountains National Park, Ethiopia, over 50 years of fire-exclusion policy: Lessons for REDD+
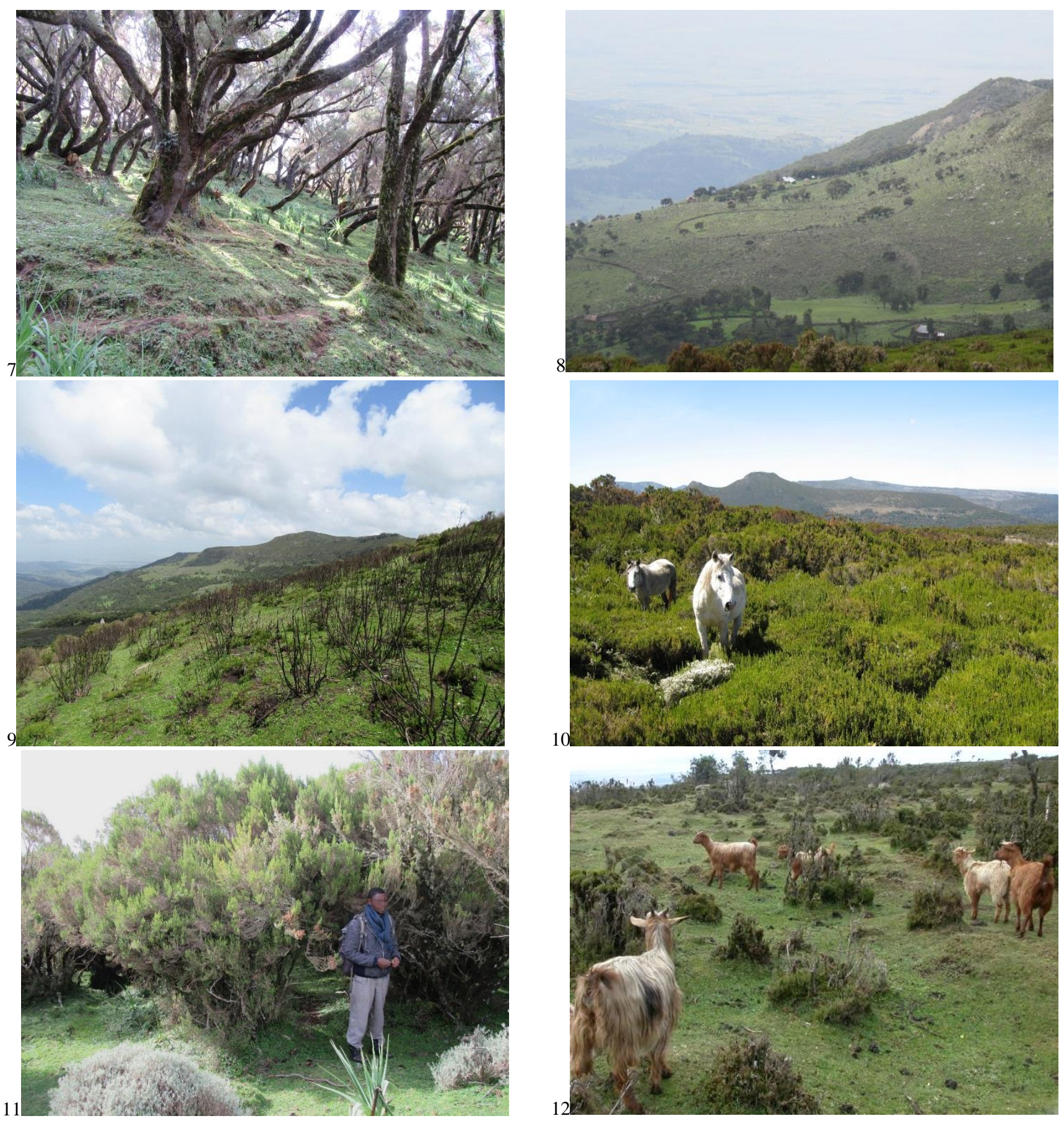
Appendix 2 - Interview questions to: Change in heathland fire sizes inside vs. outside the Bale Mountains National Park, Ethiopia, over 50 years of fire-exclusion policy: Lessons for REDD+
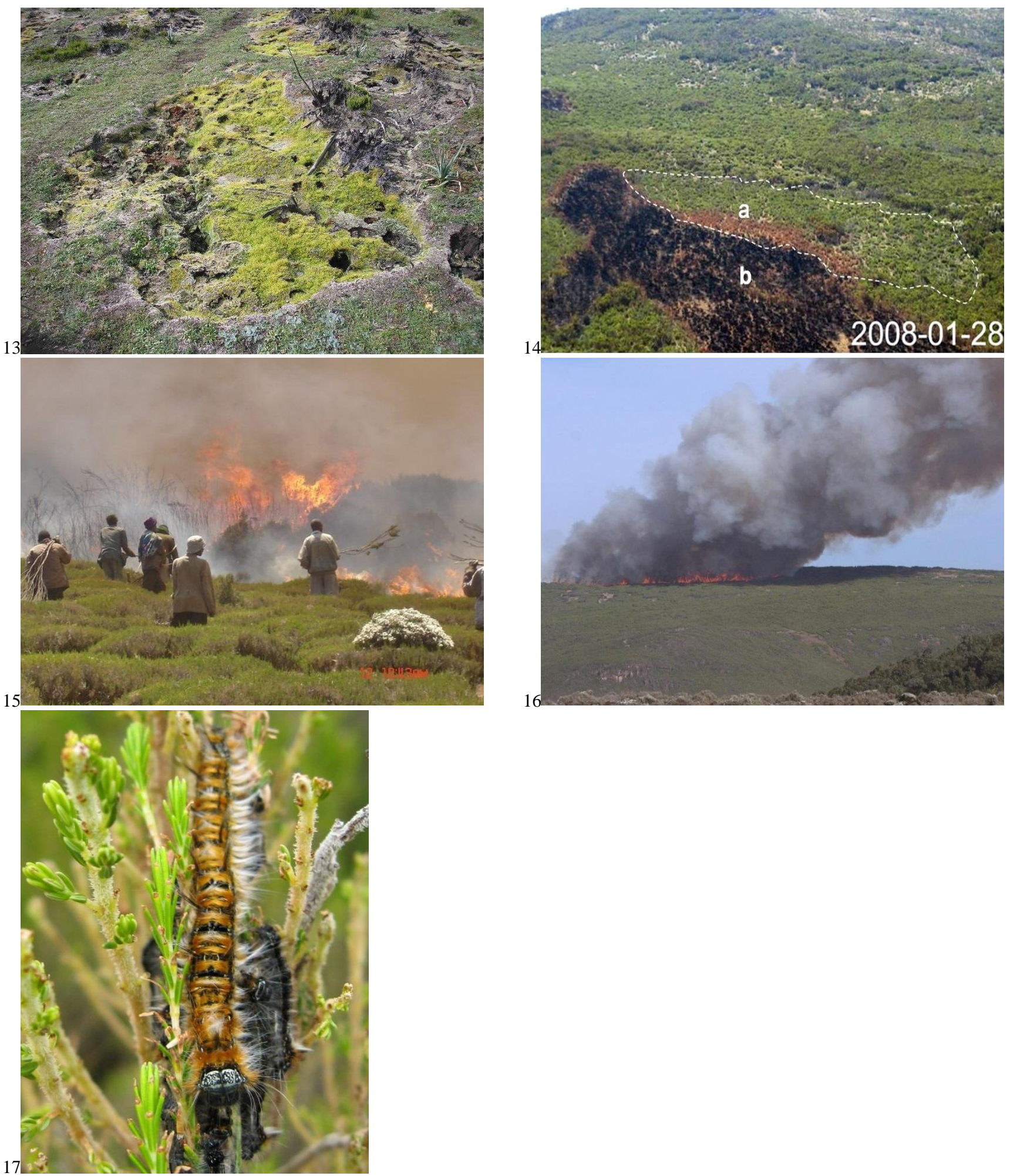